\title{
Synthesis, bioactivity, 3D-QSAR studies of novel dibenzofuran derivatives as PTP-MEG2 inhibitors
}

\author{
Ying Ma ${ }^{1, *}$, Hui-Yu Wei ${ }^{1,2, *}$, Yu-Ze Zhang ${ }^{1}$, Wen-Yan Jin ${ }^{1}$, Hong-Lian Li ${ }^{1}$, Hui Zhou ${ }^{1}$, \\ Xian-Chao Cheng ${ }^{1}$, Run-Ling Wang ${ }^{1}$ \\ ${ }^{1}$ Tianjin Key Laboratory on Technologies Enabling Development of Clinical Therapeutics and Diagnostics (Theranostics), \\ School of Pharmacy, Tianjin Medical University, Tianjin, China \\ ${ }^{2}$ Eye Hospital, Tianjin Medical University, School of Optometry and Ophthalmology, Tianjin Medical University, Tianjin, China \\ *These authors contributed equally to this work
}

Correspondence to: Xian-Chao Cheng, email: chengxianchao@tmu.edu.cn

Run-Ling Wang, email: wangrunling@tmu.edu.cn

Keywords: PTP-MEG2, dibenzofuran, synthesis, 3D-QSAR, docking

Received: January 30, $2017 \quad$ Accepted: March 17, 2017

Published: March 27, 2017

Copyright: Ying Ma et al. This is an open-access article distributed under the terms of the Creative Commons Attribution License 3.0 (CC BY 3.0), which permits unrestricted use, distribution, and reproduction in any medium, provided the original author and source are credited.

\section{ABSTRACT}

PTP-MEG2 plays a critical role in the diverse cell signalling processes, so targeting PTP-MEG2 is a promising strategy for various human diseases treatments. In this study, a series of novel dibenzofuran derivatives was synthesized and assayed for their PTP-MEG2 inhibitory activities. 10a with highest inhibitory activity (320 nM) exhibited significant selectivity for PTP-MEG2 over its close homolog SHP2, CDC25 $\left(\mathrm{IC}_{50}>50 \mu \mathrm{M}\right)$. By means of the powerful "HipHop" technique, a 3D-QSAR study was carried out to explore structure activity relationship of these molecules. The generated pharmacophore model revealed that the one RA, three Hyd, and two HBA features play an important role in binding to the active site of the target protein-PTP-MEG2. Docking simulation study indicated that 10 a achieved its potency and specificity for PTPMEG2 by targeting unique nearby peripheral binding pockets and the active site. The absorption, distribution, metabolism and excretion (ADME) predictions showed that the 11 compounds hold high potential to be novel lead compounds for targeting PTPMEG2. Our findings here can provide a new strategy or useful insights for designing the effective PTP-MEG2 inhibitors.

\section{INTRODUCTION}

Protein tyrosine phosphatases (PTPs) have been hot topics of research in biomedical science for the past two decades, and a number of PTPs have been involved in various human diseases, such as diabetes, autoimmune, cancer, and neurological disease [1-3]. Thus, the PTPs are now known as novel platforms for therapeutic intervention in human disease $[4,5]$.

Protein tyrosine phosphotase Meg2 (PTP-MEG2), an intracellular phosphatase belonging to the PTPs family, was originally cloned from human MEG-01 megakarocyte and umbilical vein endothelial cell cDNA libraries [6]. It is widely expressed in brain, leukocytes, endocrine, and exocrine cells and located on the cytoplasmic face of secretory vesicles $[6,7]$. The enzyme is composed of two domains, namely catalytic domain and Sec14p homology domain. The catalytic domain located at the
C-terminus has a sequence identity of about $30-40 \%$ in the catalytic domains with other known PTPs; while the other non-catalytic domain displays $24-29 \%$ sequence identity to cellular retinal dehyde-binding protein (CRALBP), $\alpha$-tocopherol transfer protein, and yeast Sec14p $[8,9]$. Molecular biology and genetic studies have shown that PTP-MEG2 plays a critical role in the diverse cell signalling processes [6, 10-14]. Owing to the highly homologous to Sec14p, which acts as a phosphatidylinositol transfer protein through the Golgi complex, PTP-MEG2 may also play a significant role in regulating the transfer of lipid molecules [15]. Moreover, the expression of PTP-MEG2 is elevated in polycythemia vera erythroid progenitor cells and is essential for growth and expansion of erythroid cells [16]. In addition, studies demonstrated that PTP-MEG2 inhibited insulin-induced phosphorylation of the insulin receptor, and depletion of PTP-MEG2 in the diabetic mice enhanced the insulin 
sensitivity, suggesting that it acts as a mediator of blood glucose homeostasis which in turn may be an effective drug target for treating type 2 diabetes [17]. Furthermore, it promotes intracellular secretary homotypic vesicle fusion in hematopoietic cells, and dephosphorylation of epidermal growth factor receptor (EGFR) and ErbB2 resulted in the impaired activation of Signal transducer and activator of transcription 3 (STAT3) and Signal transducer and activator of transcription 5 (STAT5) in breast cancer cells [18, 19]. Taken together, these data suggest that targeting PTP-MEG2 is a promising strategy for various human diseases treatments.

Unfortunately, PTP-MEG2 presents several key challenges in drug development due to the highly conserved PTP active sites which makes it difficult to discover compounds that could selectively inhibit single PTP protein, and the positively charged PTP-MEG2 active site which makes it tough to discover drugs that could get through the cell [20]. Despite these challenges, selective PTP-MEG2 inhibitor drug discovery could serve not only as chemical probes to understand how the normal physiology and pathological conditions controlled by tyrosine phosphorylation, but also as novel drugs for human diseases.

Until recently, one PTP-MEG2 inhibitorcompound7 had been developed, which could augment insulin signaling and enhance the insulin sensitivity and glucose homeostasis in diet-induced obese mice [20]; Wang group reported that compounds $4 \mathrm{a}$ and $4 \mathrm{~b}$ inhibited PTP-MEG2 activity with an $\mathrm{IC}_{50}$ of $3.2 \mu \mathrm{M}$ and $4.3 \mu \mathrm{M}$, respectively, which showed modest selectivity against protein tyrosine phosphatase $1 \mathrm{~B}$ (PTP1B) and $\mathrm{T}$ cell protein tyrosine phosphatase (TCPTP) [21]. Dibenzofurans and derivatives are mainly biosynthesized by lichens and ascomycetes [22]. To the best of our knowledge, many reports have been dedicated to study the biological activities of dibenzofurans on usnic acid and more specifically its cytotoxic and antibacterial activities [23]. However, owing to their low abundance in nature, other derivatives remained less studied. Few studies published on biological activities of dibenzofurans as PTP-MEG2 inhibitors. In this study, some dibenzofurans derivatives were synthesized and assayed for their PTPMEG2 inhibitory activities, hoping to discover some potential PTP-MEG2 inhibitors. In the present work we reported the synthesis of dibenzofuran derivatives with $3 \mathrm{D}$ pharmacophore study. The technique of CDOCKER was utilized to analyze the binding interactions between the inhibitors and PTP-MEG2 and the technique of ADME was used to evaluate the drugability of hit compounds in hoping that the findings thus obtained may validate the observed pharmacological properties and provide useful insights for developing novel and powerful drugs against human diseases.

\section{RESULTS AND DISCUSSION}

\section{Chemistry}

The synthetic strategy to prepare the target compounds is illustrated in Schemes 1-2. The carboncarbon double bonds intermediate compound 2 was prepared from 1-(2-fluoro-4-methoxyphenyl)ethan-1-one and methyl triphenyl phosphonium bromide by Wittig reactions, followed by hydrogen reduction with $\mathrm{Pd} / \mathrm{C}$ as catalyst under $4 \mathrm{~atm}$ of hydrogen to afford compound 3, which was iodinated with iodine catalyzed by silver sulfate to give compound 4. The key intermediate compound 5 was achieved through compound 4 and propargyl alcohol with $\mathrm{Pd}$ and $\mathrm{Cu}$ as catalyst by Sonogashira reaction [24]. Oxidization of compound 5 by manganese dioxide followed by Wittig reaction and cyclization gave compound 8 for two steps [25]. Subsequently, alcolization of compound 8 and amidation of compound 8 and then reaction of compound $9 \mathrm{a}$ and compound $9 \mathrm{~b}$ with halohydrocarbon by Williamson reaction afforded analogues compound 10a-10d. Next hydrolyzation of compound $10 \mathrm{a}-10 \mathrm{~d}$ with $2 \mathrm{~N} \mathrm{NaOH}$ aqueous solution followed by esters synthesis with halogenated hydrocarbon gave analogues compound 11a-11e.

The structures of all the newly synthesized compounds were characterized by ${ }^{1} \mathrm{H}$ NMR, ${ }^{13} \mathrm{C} \mathrm{NMR}$, ESI-MS.

\section{Biological evaluation}

Table 1 listed the PTP-MEG2 inhibitory activities of the 11 dibenzofuran derivatives. It can be seen from Table 1 that most of these molecules exhibited mild inhibitory activities against human PTP-MEG2 with $\mathrm{IC}_{50}$ values at about $0.32-5.35 \mu \mathrm{M}$. 10a showed the most potent PTP-MEG inhibitory activity with the $\mathrm{IC}_{50}$ value at $0.32 \mu \mathrm{M}$.

All the molecules were substituted in part $R_{1}$ and $R_{2}$. The most active molecule $10 \mathrm{a}\left(\mathrm{R}_{1}=\right.$ cyclopropylmethyl, $\mathrm{R}_{2}=$ ethyl) and other molecules with suitable hydrophobic groups in these two positions $(8,10 \mathrm{a}, 10 \mathrm{~b}, 10 \mathrm{c}, 10 \mathrm{~d}, 11 \mathrm{a}$, $11 \mathrm{~b}, 11 \mathrm{c}$, and 11d) were more active than the unsubstituted ones in either of the two places ( $9 a$ and 11e). Besides, by comparison with the activities between compounds 10b-10d and 11a-11d, it was found that remaining bulky aromatic group (4-methoxybenzyl) at $\mathrm{R}_{1}$ and modifying at $R_{2}$ revealed that increased steric bulk was preferred in the position $\mathrm{R}_{2}$ to improve the activity (the order of inhibition was $11 \mathrm{~d}>11 \mathrm{~b}>10 \mathrm{~d}$ ), whereas remaining hydrophobic group (hexyl) at $\mathrm{R}_{1}$ and modifying at $\mathrm{R}_{2}$ indicated that increased steric bulk led to significantly decrease in the inhibitory activity (the order of inhibition was $11 \mathrm{c}<11$ a $<10$ b). In addition, variation of the alkyl group at $\mathrm{R}_{1}$ and remaining small size alkyl group (ethyl) at $\mathrm{R}_{2}$ showed that 


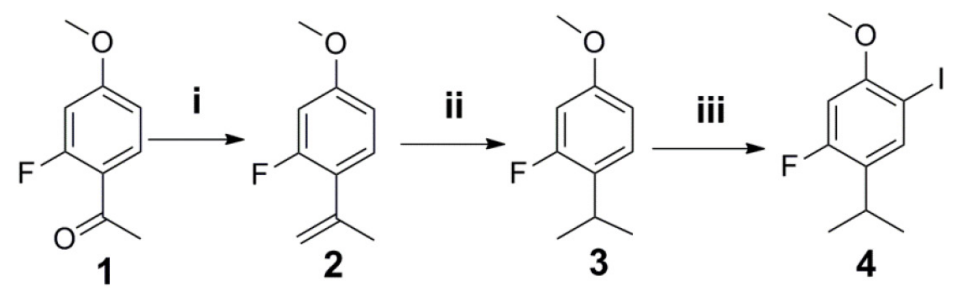<smiles>CCOC(=O)C(C#Cc1cc(C(C)C)c(F)cc1OC)=CC#Cc1cc(C(C)CC#CC(C)CC=O)c(F)cc1OC</smiles><smiles>CCOC(=O)c1cc(O[13CH3])c2c(c1)oc1cc(F)c(C(C)C)cc12</smiles>

Scheme 1: Reagents and conditions: (i) $\mathrm{n}-\mathrm{BuLi}, \mathrm{Ph} 3 \mathrm{PCH} 3 \mathrm{Br}$, THF, 96\%; (ii) $\mathrm{Pd} / \mathrm{C}, \mathrm{H} 2,4 \mathrm{~atm}, \mathrm{MeOH}, 91 \%$; (iii) I2, Ag2SO4, MeOH, 90\%; (iv) (Ph3P)2PdCl2, CuI, Et3N, THF, prop-2-yn-1-ol, 84\%; (v) MnO2, DCM, 80\%; (vi) Toluene, overnight, 67\%; (vii) Ac2O,NaOAc, hydroquinone, reflux, 78\%.

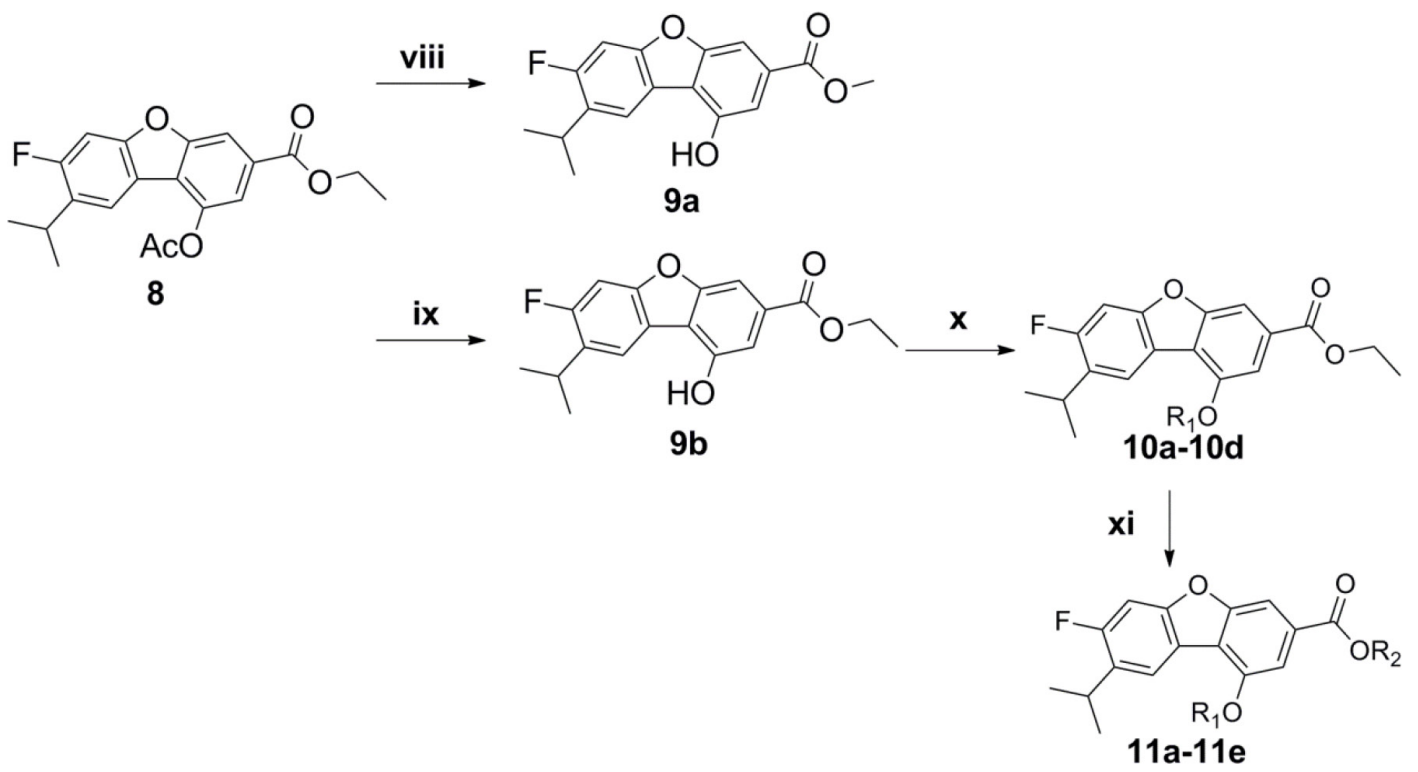

Scheme 2: Reagents and conditions: (viii) $\mathrm{MeONa}, \mathrm{MeOH}, 62 \%$; (ix) HNEt2, MeOH; (x) K2CO3, R1-Br, acetone; (xi) $\mathrm{K} 2 \mathrm{CO} 3, \mathrm{R} 2-\mathrm{Br}$, acetone.
10a: $\mathrm{R}_{1}=$ cyclopropylmethyl
$10 \mathrm{~b}: \mathrm{R}_{1}=$ hexyl
$10 \mathrm{c}: \mathrm{R}_{1}=$ cyclohexylmethyl
$10 \mathrm{~d}: \mathrm{R}_{1}=4$-methoxybenzyl

11a: $\mathrm{R}_{1}=$ hexyl

11b: $\mathrm{R}_{1}=4$-methoxybenzyl

11c: $R_{1}=$ hexyl

11d: $\mathrm{R}_{1}=4$-methoxybenzyl

11e: $\mathrm{R}_{1}=$ cyclopropylmethyl
$\mathrm{R}_{2}=$ cyclopropylmethyl

$\mathrm{R}_{2}=$ cyclopropylmethyl

$\mathrm{R}_{2}=$ cyclohexylmethyl

$\mathrm{R}_{2}=$ cyclohexylmethyl

$\mathrm{R}_{2}=\mathrm{H}$ 


\section{Table 1: Structure and PTP-MEG2 inhibitory activity of dibenzofuran derivatives}

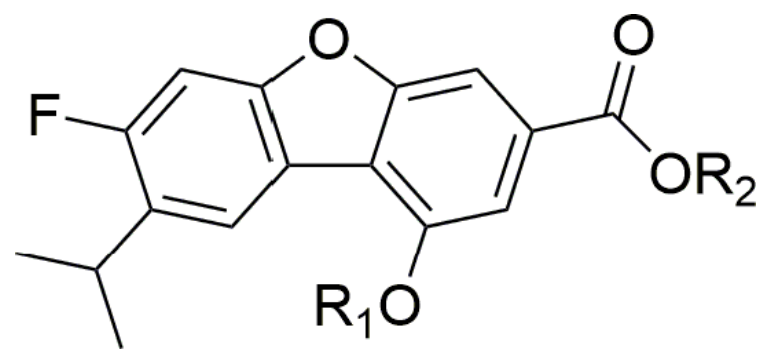

\begin{tabular}{|c|c|c|c|c|c|c|c|}
\hline Cpds & $\mathbf{R}_{1}$ & $\mathbf{R}_{2}$ & Fit values & $\begin{array}{l}\text { Docking } \\
\text { score }\end{array}$ & $\begin{array}{c}\text { PTP-MEG2 } \\
\text { IC }_{50}(\mu \mathrm{M})\end{array}$ & $\begin{array}{c}\text { SHP-2 } \\
\text { IC }_{50}(\mu M)\end{array}$ & $\begin{array}{c}\text { CDC25 } \\
\mathrm{IC}_{50}(\mu \mathrm{M})\end{array}$ \\
\hline 8 & $\mathrm{CH}_{3} \mathrm{CO}$ & ethyl & 3.42 & 24.25 & $3.7 \pm 0.22$ & $>50$ & $>50$ \\
\hline 9a & $\mathrm{H}$ & methyl & 3.34 & 22.65 & $5.0 \pm 0.40$ & $>50$ & $>50$ \\
\hline $10 \mathrm{a}$ & cyclopropylmethyl & ethyl & 6.60 & 58.28 & $0.32 \pm 0.02$ & $>50$ & $>50$ \\
\hline $10 b$ & hexyl & ethyl & 5.29 & 27.54 & $1.22 \pm 0.11$ & $>50$ & $>50$ \\
\hline $10 \mathrm{c}$ & cyclohexylmethyl & ethyl & 5.59 & 30.30 & $1.19 \pm 0.08$ & $>50$ & $>50$ \\
\hline $10 d$ & 4-methoxybenzyl & ethyl & 3.44 & 23.78 & $3.39 \pm 0.34$ & $>50$ & $>50$ \\
\hline $11 \mathrm{a}$ & hexyl & cyclopropylmethyl & 4.61 & 25.66 & $2.41 \pm 0.17$ & $>50$ & $>50$ \\
\hline 11b & 4-methoxybenzyl & cyclopropylmethyl & 6.00 & 33.29 & $1.06 \pm 0.10$ & $>50$ & $>50$ \\
\hline $11 \mathrm{c}$ & hexyl & cyclohexylmethyl & 3.56 & 26.00 & $3.16 \pm 0.32$ & $>50$ & $>50$ \\
\hline 11d & 4-methoxybenzyl & cyclohexylmethyl & 5.99 & 57.28 & $0.83 \pm 0.04$ & $>50$ & $>50$ \\
\hline $11 \mathrm{e}$ & cyclopropylmethyl & $\mathrm{H}$ & 3.01 & 17.82 & $5.35 \pm 0.43$ & $>50$ & $>50$ \\
\hline
\end{tabular}

Each experiment was performed in triplicate. Data are presented as mean \pm S.E.M.

decreased steric bulk at $\mathrm{R}_{1}$ would improve the PTP-MEG2 inhibitory activity. Consequently, the possible SARs of PTP-MEG2 inhibitors observed from the biological results is that compounds with appropriate hydrophobic and bulky substituents in parts $\mathrm{R}_{1}$ and $\mathrm{R}_{2}$ might acquire higher activities (10a, 10b, 10c, 11b, and 11d). The hypothesis will be tested in the following 3D-QSAR study.

\section{D pharmacophore studies}

We employed the HipHop module of Discovery studio v3.5 software to build reasonable 3D-common feature hypotheses. 10 optimal pharmacophoric hypotheses were created. As given in Table 2, the hypo1, hypo2, hypo5, hypo6, hypo9 and hypo10 have the same molecular features that contain two RA(ring aromatic), two Hyd (hydrophobic), and one HBA (hydrogen bond acceptor), while the hypo3, hypo4, hypo 7 and hypo8 had the same molecular features that contained one RA, three Hyd, and two HBA with different 3D spatial arrangements. To validate the resulting models, we subjected our pharmacophores to ROC (receiver operating characteristic) analysis to assess their abilities to selectively capture diverse PTP-MEG2 inhibitors from a large list of decoys. The testing set included 3 active compounds and 90 decoys searched from zinc database [26]. The ROC testing set (93 compounds) was screened by each pharmacophore for ROC analysis. In ROC analysis, the ability of a particular pharmacophore model to distinguish a list of compounds as actives or inactives was indicated by the area under the curve (AUC) of the resulting ROC as well as other two parameters: sensitivity and specificity $[27,28]$. Table 2 showed the ROC performances of our 10 optimal pharmacophores. As shown in Table 2, it can be concluded that hypo3 performed better than the other 9 pharmacophores based on ROC-AUC, sensitivity and specificity. The 3D-common feature pharmacophore-hypo3 (Figure 1) has been developed to derive the structureactivity relationships of PTP-MEG2 inhibitors. The generated 3D-common feature pharmacophore hypothesis containing one RA, three Hyd, and two HBA was applied to explain the pharmacophoric site specifications of the PTP-MEG2 inhibitory activities of dibenzofuran derivatives. The generated pharmacophore model revealed that the one RA, three Hyd, and two HBA features played an important role in binding to the active site of the target protein-PTP-MEG2. One RA and three Hyd features demonstrated the appropriate active shape of the molecule, displaying the required placement of aromatic moiety and hydrophobic group. Two HBA features at the given positions were vital in the molecule to bind to the 
Table 2: HipHop-generated hypotheses and validation with known actives/inactives

\begin{tabular}{cccccccccccc}
\hline Hypotheses & features & Rank & $\begin{array}{c}\text { Total } \\
\text { actives }\end{array}$ & $\begin{array}{c}\text { Total } \\
\text { inactives }\end{array}$ & $\begin{array}{c}\text { True } \\
\text { positives }\end{array}$ & $\begin{array}{c}\text { True } \\
\text { negatives }\end{array}$ & $\begin{array}{c}\text { False } \\
\text { positives }\end{array}$ & $\begin{array}{c}\text { False } \\
\text { negatives }\end{array}$ & Sensitivity & specificity & RoC \\
\hline hypo1 & RRHHA & 102.706 & 3 & 90 & 2 & 73 & 17 & 1 & 0.6667 & 0.81111 & 0.706 \\
hypo2 & RRHHA & 102.706 & 3 & 90 & 2 & 75 & 15 & 1 & 0.6667 & 0.83333 & 0.806 \\
hypo3 & RHHHAA & 102.151 & 3 & 90 & 2 & 79 & 11 & 1 & 0.6667 & 0.87778 & 0.994 \\
hypo4 & RHHHAA & 102.151 & 3 & 90 & 2 & 72 & 18 & 1 & 0.6667 & 0.80000 & 0.694 \\
hypo5 & RRHHA & 101.727 & 3 & 90 & 2 & 76 & 14 & 1 & 0.6667 & 0.84444 & 0.883 \\
hypo6 & RRHHA & 101.707 & 3 & 90 & 2 & 76 & 14 & 1 & 0.6667 & 0.84444 & 0.883 \\
hypo7 & RHHHAA & 100.889 & 3 & 90 & 2 & 71 & 19 & 1 & 0.6667 & 0.78889 & 0.787 \\
hypo8 & RHHHAA & 100.889 & 3 & 90 & 2 & 73 & 17 & 1 & 0.6667 & 0.81111 & 0.804 \\
hypo9 & RRHHA & 99.090 & 3 & 90 & 2 & 76 & 14 & 1 & 0.6667 & 0.84444 & 0.804 \\
hypo10 & RRHHA & 99.090 & 3 & 90 & 2 & 73 & 17 & 1 & 0.6667 & 0.81111 & 0.726 \\
\hline
\end{tabular}

target protein. As we can see from the pharmacophore, the essentials for the specification of PTP-MEG2 inhibitory activity of dibenzofuran derivatives are listed as follows: 1) the ring aromatic property of the fluoro-phenyl group in the fused ring system; 2) the hydrophobic property of the isopropyl group and the phenyl group in the fused ring system, and the ethyl moiety at $\mathrm{R}_{2} ; 3$ ) the hydrogen bond acceptor property of carbonyl oxygen and oxygen atom in the alkyloxy group in the fused ring system. The mapping of $10 \mathrm{a}$, as a representative, in hypo-3 was shown in Figure 1. As shown in Supplementary Figure 1, 10a and $11 \mathrm{~d}$ mapped all the features in hypo-3, which might explain why $10 \mathrm{a}$ and $11 \mathrm{~d}$ possessed higher potent activities than the other molecules. Interestingly, 10a had small size alkyl group at $\mathrm{R}_{1}$ and $\mathrm{R}_{2}$, while $11 \mathrm{~d}$ possessed large steric bulk at $\mathrm{R}_{1}$ and $\mathrm{R}_{2}$. Although $11 \mathrm{~d}, 11 \mathrm{~b}$ and $10 \mathrm{~d}$ were substituted by same bulky aromatic group $\left(4-\mathrm{CH}_{3} \mathrm{OOCphCH}_{2}\right)$ at $\mathrm{R}_{1}$, and $10 \mathrm{~b}, 11 \mathrm{a}$ and $11 \mathrm{c}$ were substituted by same steric bulk group (hexyl) at $R_{1}$, all of them mapped the features in hypo-3 in the same way. 11d hold a bulky aromatic group at $R_{2}$, rather than having small size group at $R_{2}$, such as $11 \mathrm{~b}$ and $10 \mathrm{~d}$, possessed a better match with all the features in the model. However, 10b had small size alkyl group at $\mathrm{R}_{2}$, rather than having large size group at $\mathrm{R}_{2}$, such as $11 \mathrm{a}$ and $11 \mathrm{c}$, possessed a better match with all the features in the model. 9a and 11e with the unsubstituted ones in either of $R_{1}$ and $R_{2}$ missed the Hyd feature. From the above, compounds with appropriate hydrophobic and bulky

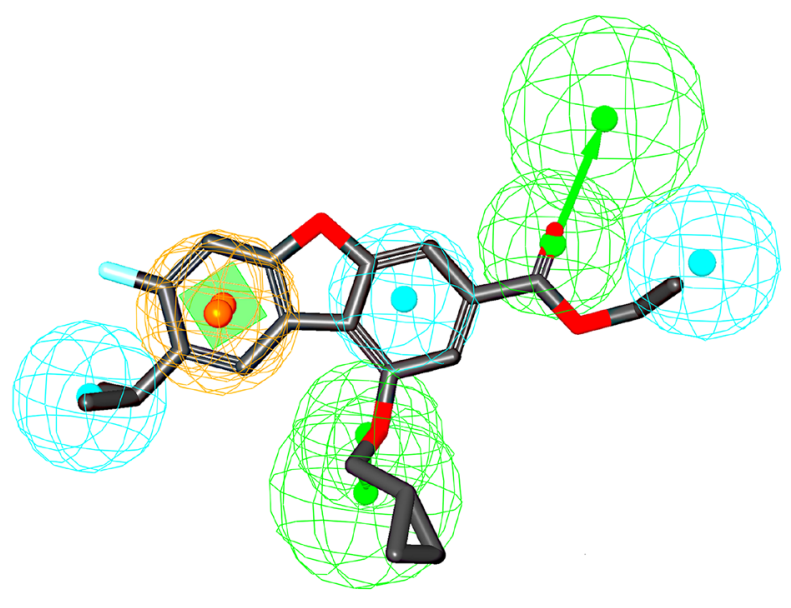

A

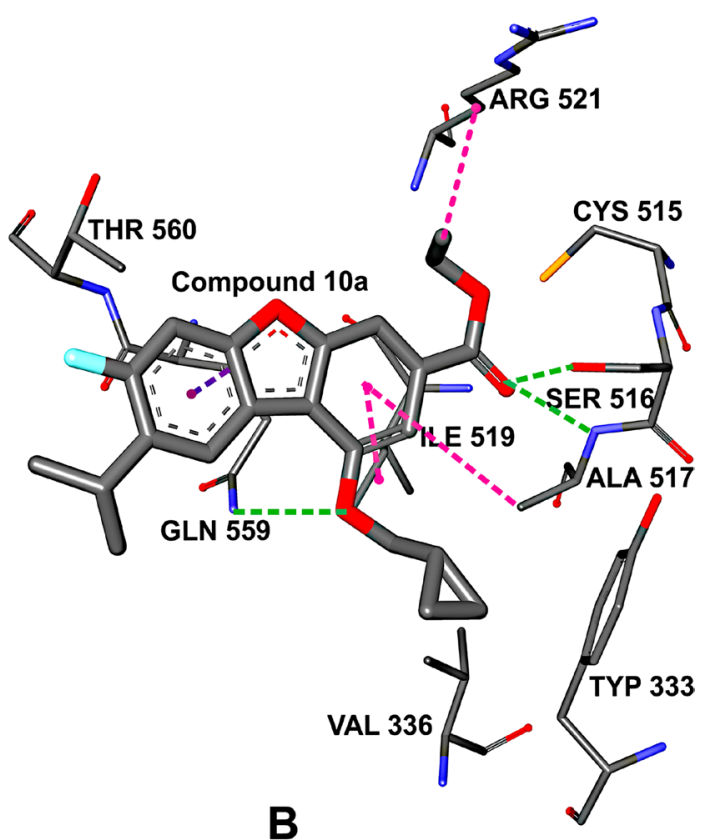

Figure 1: (A) Illustration to show the hypo3 generated by Hypogen. The best Hypogen model hypo-3-PTP-MEG2 mapped with Compound 10a. The features are colored coded with green, hydrogen-bond acceptor; cyan, hydrophobic; brown, ring aromatic. (B) Interaction of the receptor with the docked Compound 10a. The green dotted lines indicate the H-bond interactions of the receptor with Compound 10a. The purple dotted lines indicate the hydrophobic interactions of the receptor with Compound 10a. 
substituents in parts $R_{1}$ and $R_{2}$ would match with all the mapped common features in the anticipated model, which was consistent with the experimental data.

\section{Molecular docking}

The model was obtained by docking ligand to the PTP-MEG2 domain (from PDB 4GE6) using the methods we have described in materials and methods section. The 10a, ranked the first in the fit value and in the PTP activity assay, inhibited the activity of PTP-MEG2 with an $\mathrm{IC}_{50}$ of $320 \mathrm{nM}$. 10a exhibited significant selectivity for PTP-MEG2 over its close homolog SHP2, CDC25 $\left(\mathrm{IC}_{50}>50 \mu \mathrm{M}\right)$. The preferred co-ordination mode of $10 \mathrm{a}$ is described in Figure 1. To assess the hypo3-PTPMEG2, we compared the pharmcophore model with the active site of PTP-MEG2. The hypo3-PTP-MEG2 model consists of one RA, three Hyd, and two HBA (Figure 1A). The HBAs are oriented to interact with the nucleophilic catalytic residues: Ser 516, Ala 517, and Gln 559. The Hyd is pointed towards Ala517, Ile 519 and Arg521 and the RA is oriented to interact with Gln 559. A close-up view for the protein-ligand interactions at the binding pocket thus defined is shown in Figure 1B. The results of receptor-ligand interactions obtained from the docking simulation had proved that the key residues for the binding interactions between 10a and the receptor were fully consistent with the previous reports [20]. 10a is found in the PTP-MEG2 active-site pocket and forms extensive interactions with residues in the P-loop (residues 514-521), the pTyr recognition loop (residues 331-338), and the Q-loop (residues 558-564). The O19 atom of 10a makes two hydrogen bonds [29] with the main chain amides Ser516 and Ala 517of the P-loop; The $\mathrm{O} 21$ atom of 10a also forms one hydrogen bond with Gln559 of the Q-loop. In addition to the polar interactions, the dibenzofuran group participates in hydrophobic interactions with Ile519, Ala517 in the P-loop and Gln559 in the Q-loop. The dibenzofuran group is involved in pisigma hydrophobic interaction [30] with Gln559 and two pi-alkyl hydrophobic interactions with Ala517 and Ile 519. The $\mathrm{C} 25$ atom of $10 \mathrm{a}$ is engaged in alkyl hydrophobic interaction [31] with Arg521 in Q-loop. The 2D diagram of PTP-MEG2-10a, interactions were shown in Supplementary Figure 2, pink plates such as Cys515, Ser516, Ala517, Gly518, Ile519, Gly520, Arg521, Gln559, Gln563 were involved in hydrogen bonding, charge or polar interactions, while green plates like Tyr307, Arg311, Tyr333, Asp335, Val336,Lys411, Thr522, Thr560, Pro561 represented van der waals interactions. Interestingly, Pro561 is unique to PTP-MEG2, which means no other PTPs have the same amino acids at the corresponding positions. It is likely that the van der waals interactions between dibenzofuran group were responsible for the potency and selectivity of 10a. Collectively, the structural observations offered direct evidence that $10 \mathrm{a}$ achieved its potency and specificity for PTP-MEG2 by targeting unique nearby peripheral binding pockets as well as the active site.

\section{ADME}

Some molecular properties of the dibenzofuran derivatives such as the AlogP, molecular weight, number of aromatic ring, number of $\mathrm{H}$-acceptors, number of $\mathrm{H}$-donors, number of rings, number of aromatic rings, number of rotatable bonds, molecular fraction polar surface area were calculated by "Calculate Molecular Properties" module of the Discovery Studio v3.5. Some pharmacokinetic properties of these derivatives such as PSA, Solubility, human intestinal absorption, blood brain barrier, cytochrome p450 2D6, protein binding, and hepatotoxicity plasma were also predicted by Discovery Studio v3.5. The results thus obtained are listed in the Tables 3 and 4, respectively. Results of pharmacokinetic screening indicated that $8,9 \mathrm{a}, 10 \mathrm{a}, 10 \mathrm{c}, 11 \mathrm{~b}, 11 \mathrm{c}, 11 \mathrm{~d}, 11 \mathrm{e}$ followed the Lipinski's rule of five for oral bioavailability. Human Intestinal Absorption (HIA) and solubility are two key factors that affect oral bioavailability. Without moderate to high intestinal absorption, the therapeutic effect of drugs can appreciably diminish. Solubility has a pronounced effect on the pharmacological activity of a compound in terms of its uptake, distribution, and ultimately bioavailability. The compound $10 \mathrm{~b}, 10 \mathrm{c}, 11 \mathrm{a}$ and 11c showed lipophilic nature due to high $\log P$ value, while compound 11d showed both high lipophilicity and low human intestinal absorption due to high $\log P$ and molecular weight. CYP2D6 is responsible for the metabolism and elimination of approximately $25 \%$ of clinically used drugs. The inhibition of CYP2D6 by a drug constitutes the majority cases of drug-drug interaction. Ten compounds were predicted to be non-inhibitors of cytochrome P450 2D6 (CYP2D6), which is one of the important enzymes involved in drug metabolism. The predicted plasma protein binding parameter is an important parameter for drug distribution. All compounds were found to be highly bound with plasma protein. For hepatotoxicity, nine compounds were predicted nontoxic. For brain/blood barrier, compound 10a had a good penetrant level, and three compounds had a moderate penetrant level. Therefore, as mentioned above, the values for the ADME properties of compound 10a, 10c, 11b, 11c, and $11 \mathrm{~d}$ listed in Table 4 are within the acceptable range for human beings, indicating these compounds found in this study can be utilized as candidates for the purpose of developing new drugs.

\section{CONCLUSIONS}

The goal of this study was to synthesize a series of dibenzofuran derivatives and evaluate the PTP-MEG2 inhibitory activities of these compounds. 3D-QSAR study 
Table 3: Molecular properties for the dibenzofuran derivatives

\begin{tabular}{|c|c|c|c|c|c|c|c|c|}
\hline & TPSA & $\begin{array}{c}\text { Num } \\
\text { H_Donors }\end{array}$ & $\begin{array}{c}\text { Num } \\
\text { H_Acceptors }\end{array}$ & $\begin{array}{c}\text { Num } \\
\text { RotatableBonds }\end{array}$ & $\begin{array}{l}\text { Num } \\
\text { Rings }\end{array}$ & $\begin{array}{c}\text { Num } \\
\text { AromaticRings }\end{array}$ & $\begin{array}{l}\text { Lipinski } \\
\text { rules }\end{array}$ & Molecular_weigh \\
\hline 8 & 65.74 & 0 & 4 & 6 & 3 & 3 & pass & 358.36 \\
\hline $9 \mathrm{a}$ & 59.67 & 1 & 3 & 3 & 3 & 3 & pass & 302.297 \\
\hline $10 \mathrm{a}$ & 48.67 & 0 & 3 & 7 & 4 & 3 & pass & 370.14 \\
\hline $10 \mathrm{~b}$ & 48.67 & 0 & 3 & 10 & 3 & 3 & failed & 400.483 \\
\hline $10 \mathrm{c}$ & 48.67 & 0 & 3 & 7 & 4 & 3 & pass & 412.494 \\
\hline $10 \mathrm{~d}$ & 57.9 & 0 & 4 & 8 & 4 & 4 & failed & 436.472 \\
\hline $11 \mathrm{a}$ & 48.67 & 0 & 3 & 11 & 4 & 3 & failed & 426.52 \\
\hline $11 b$ & 57.9 & 0 & 4 & 9 & 5 & 4 & pass & 462.509 \\
\hline $11 \mathrm{c}$ & 48.67 & 0 & 3 & 11 & 4 & 3 & pass & 468.6 \\
\hline $11 d$ & 57.9 & 0 & 4 & 9 & 5 & 4 & pass & 504.589 \\
\hline $11 \mathrm{e}$ & 62.5 & 0 & 3 & 5 & 4 & 3 & pass & 342.361 \\
\hline
\end{tabular}

Table 4: The ADME prediction for the dibenzofuran derivatives

\begin{tabular}{|c|c|c|c|c|c|c|c|c|}
\hline & $A \log P^{a}$ & Solubility-level $^{\mathrm{b}}$ & BBB-Level $^{\mathrm{c}}$ & $\begin{array}{c}\text { CYP2D6 } \\
\text { Prediction }\end{array}$ & $\begin{array}{c}\text { Hepatotoxic\# } \\
\text { Prediction }\end{array}$ & Absorption-level $^{\mathrm{d}}$ & $\begin{array}{c}\text { PPB\# } \\
\text { Prediction }\end{array}$ & PSA_2D \\
\hline 8 & 4.705 & 2 & 1 & False & True & 0 & True & 65.016 \\
\hline $9 \mathrm{a}$ & 4.346 & 2 & 1 & False & True & 0 & True & 59.6 \\
\hline $10 \mathrm{a}$ & 5.741 & 1 & 0 & False & False & 0 & True & 47.715 \\
\hline $10 \mathrm{~b}$ & 7.161 & 0 & 4 & True & False & 3 & True & 47.715 \\
\hline $10 \mathrm{c}$ & 7.109 & 0 & 4 & False & False & 3 & True & 47.715 \\
\hline $10 \mathrm{~d}$ & 6.488 & 1 & 4 & True & False & 1 & True & 56.645 \\
\hline $11 \mathrm{a}$ & 7.633 & 0 & 4 & True & False & 3 & True & 47.715 \\
\hline $11 b$ & 6.959 & 1 & 4 & False & False & 2 & True & 56.645 \\
\hline $11 \mathrm{c}$ & 9.001 & 0 & 4 & False & False & 3 & True & 47.715 \\
\hline $11 d$ & 8.328 & 0 & 4 & False & False & 3 & True & 56.646 \\
\hline $11 \mathrm{e}$ & 5.166 & 2 & 1 & False & True & 0 & True & 56.085 \\
\hline
\end{tabular}

a:AlogP, the logarithm of the partition coefficient between n-octanol and water; b:Aqueous solubility level: 0 (extremely low); 1 (very low, but possible); 2 (low); 3 (good);c: BBB level: 0 (very good); 1 (good); 2 (moderate); 3 (poor);4(undefined); d: Human intestinal absorption level: 0 (good); 1 (moderate); 2 (poor); 3 (very poor).

using HipHop methods was applied to study the structureactivity relationship. The best hypothesis contains one RA, three Hyd, and two HBA. The compounds with appropriate hydrophobic and bulky substituents in parts $R_{1}$ and $R_{2}$ would match with all the mapped common features in the anticipated model. It is interesting to discover that $10 \mathrm{a}$ exhibited significant selectivity for PTP-MEG2 (320 nM) over its close homolog SHP2, CDC25 $\left(\mathrm{IC}_{50}>50 \mu \mathrm{M}\right)$. Through molecular docking, a most likely binding mode was proposed, suggesting that the potency and selectivity of the PTP-MEG2 inhibitors could be achieved by targeting peripheral pockets and the active site. It was further validated by the outcomes of their ADME predictions that the new inhibitors hold high potential to become drug candidates. Or at the very least, our 3D QSAR model can be useful and predictive tool to develop novel PTP-MEG2 inhibitors.

\section{MATERIALS AND METHODS}

\section{Chemistry}

\section{General}

All the reagents were purchased from commercial suppliers and were used without further purification unless otherwise indicated. All the reactions were monitored by 
thin-layer chromatography (TLC) on silica gel precoated F254 Merck plates, and spots were examined under UV light $(254 \mathrm{~nm})$. All column chromatography was performed using 200-300 mesh silica gel. ${ }^{1} \mathrm{H}$ NMR and ${ }^{13} \mathrm{C}$ NMR spectra were taken on a Bruker Avance 300-MHz NMR Spectrometer at $300 \mathrm{~K}$ with TMS as the internal standard, and $\mathrm{CDCl}_{3}$ and DMSO- $\mathrm{d}_{6}$ were used as solvent, the values of the chemical shifts $(\delta)$ are expressed in parts per million (ppm), and coupling constants $(\mathrm{J})$ are expressed in hertz $(\mathrm{Hz})$. MS spectra were recorded on an Agilent 1100 LC/MSD (ESI) Mass Spectrum.

\section{General method I: Williamson ether synthesis reaction}

To a well stirred solution of compound $9 \mathrm{~b}(0.1 \mathrm{~g}$, $1 \mathrm{mmol})$ in anhydrous acetone, was added Cesium Carbonate $\left(\mathrm{Cs}_{2} \mathrm{CO}_{3}\right)(0.63 \mathrm{~g}, 2 \mathrm{mmol})$ and (bromomethyl) cyclopropane $(0.1 \mathrm{~g}, 2 \mathrm{mmol})$, the mixture was heated at reflux overnight under $\mathrm{N}_{2}$ atmosphere anhydrous when most of the starting materials were converted into the target compound. The mixture was filtrated over a pad of celite and washed with chloroform. The precipitated product was collected by filtration, and further purified by silica gel column chromatography with $10 \% \sim 12 \%$ ethyl acetate in petroleum ether as elute to afford the final product.

\section{General method II: Carboxylic acid ester hydrolysis reaction}

A mixture of carboxylic acid ester derivatives $(0.15 \mathrm{mmol})$ and $2 \mathrm{~N} \mathrm{NaOH}$ aqueous solution $(10 \mathrm{~mL})$ in $\mathrm{MeOH}(10 \mathrm{~mL})$ was stirred at ambient temperature overnight. TLC and LC-MS examination showed that most of the starting materials were converted into the target compound. After the reaction, the mixture was acidified to $\mathrm{pH} 2$ with $1 \mathrm{~N} \mathrm{HCl}$ aqueous solution. Subsequently, the crude product was washed with water $(2 \times 10 \mathrm{~mL})$, and was air-dried to give crude product.

\section{General method III: Esters synthesized reaction}

To a well stirred solution of carboxylic acid ester derivatives $(0.15 \mathrm{mmol})$ in acetone $(20 \mathrm{~mL})$ was added halogenated hydrocarbon $(0.15 \mathrm{mmol})$ and $\mathrm{Cs}_{2} \mathrm{CO}_{3}$ $(0.30 \mathrm{mmol})$. The result mixture was heated at reflux until most of the carboxylic acid ester derivative was converted into the target compound. Then, the mixture was separated with a funnel and aqueous phase was extracted with ethyl acetate. The combined organic phases were washed with brine and dried over anhydrous $\mathrm{Na}_{2} \mathrm{SO}_{4}$. After filtration and concentration, the residual was purified by column chromatography (200-300 mesh silica gel, 10 12\% ethyl acetate in $\mathrm{PE}$ ). 2-fluoro-4-methoxy-1-(prop-1-en-2-yl) benzene (2)

Under $\mathrm{N}_{2}$ atmosphere, to a solution of methyl triphenyl phosphonium bromide (110 g, $310 \mathrm{mmol})$ in dry tetrahydrofuran (THF) $(550 \mathrm{~mL})$ was added BuLi (0.25 $\mathrm{mL}, 2.5 \mathrm{M}$ solution in THF) dropwise at $-65^{\circ} \mathrm{C}$ and the reaction stirred for $30 \mathrm{~min}$. Then 1-(2-fluoro-4methoxyphenyl)ethan-1- one (40 g, $238 \mathrm{mmol})$ in dry THF $(100 \mathrm{~mL})$ was added dropwise and the reaction was stirred at $-65^{\circ} \mathrm{C}$ for $1.5 \mathrm{~h}$. Then, the reaction mixture was naturally heated to room temperature and stirred at room temperature overnight. TLC and LC-MS examination showed that most of the starting material was converted into the target compound. Acetic acid was introduced into the system with stirring to quench the reaction, which was extracted with ethyl acetate $(150 \mathrm{~mL})(\times 3)$, and washed with water $(\times 2)$ and saturated brines $(\times 2)$, dried over anhydrous $\mathrm{MgSO}_{4}$ and filtered and concentrated in vacuo to give the crude product. Purification by column chromn chromatography (200-300 mesh silica gel, 8\% 20\% ethyl acetate in PE) gave final product compound 2 (38 g, yield $96 \%) .{ }^{1} \mathrm{H}$ NMR(300 MHz, $d_{6}$-DMSO) $\delta: 7.26(\mathrm{t}, 1 \mathrm{H}), 6.81$ $(\mathrm{dd}, J=8.0,2.0,1 \mathrm{H}), 6.73(\mathrm{dd}, J=8.0,2.0,1 \mathrm{H}), 5.17$ (s, 2H), 3.75 (s, 3H), 2.05 (s, 3H).

\section{2-fluoro-1-isopropyl-4-methoxybenzene (3)}

After two vacuum $/ \mathrm{H}_{2}$ cycles to replace air inside the reaction tube with hydrogen, the mixture of the compound $2(38 \mathrm{~g}, 229 \mathrm{mmol})$ and $10 \% \mathrm{Pd} / \mathrm{C}(2 \mathrm{~g})$ in $\mathrm{MeOH}(250 \mathrm{~mL})$ was vigorously stirred at room temperature under 4 atm of hydrogen for $6 \mathrm{~h}$. The reaction mixture was filtered using a membrane filter (Millipore, MillexLH, $0.45 \mu \mathrm{m}$ ), and the filtrate was concentrated to provide the compound 3 as light yellow oil(35 g, yield 91\%). The crude compound 3 was used without further purification. ${ }^{1} \mathrm{H} \mathrm{NMR}(300 \mathrm{MHz}$, $\left.\mathrm{CDCl}_{3}\right) \delta: 7.1(\mathrm{t}, 1 \mathrm{H}), 6.63(\mathrm{dd}, J=8.0,1.5,1 \mathrm{H}), 6.56(\mathrm{dd}$, $J=7.5,1.5,1 \mathrm{H}), 3.78$ (s, 3H), 3.12 (m, 1H), 1.15 (m, 6H).

\section{1-fluoro-4-iodo-2-isopropyl-5-methoxybenzene (4)}

To a well stirred solution of the compound 3 (35 g, $208 \mathrm{mmol})$ in $\mathrm{MeOH}(200 \mathrm{~mL})$ was added silver sulfate $(65 \mathrm{~g}, 208 \mathrm{mmol})$, iodine $(52 \mathrm{~g}, 208 \mathrm{mmol})$ and the reaction was stirred at room temperature for $6 \mathrm{~h}$. TLC and LC-MS examination showed that most of the starting material was converted into the target compound. The solvent was removed by rotary evaporation and the solid was filtered through Büchner funnel and the filtrate was washed with $\mathrm{MeOH}(\times 2)$. Purification by column chromn chromatography (200-300 mesh silica gel, 5\% 10\% ethyl acetate in PE) gave final product compound 4 (55 g, yield 90\%). ${ }^{1} \mathrm{H}$ NMR(300 $\left.\mathrm{MHz}, \mathrm{CDCl}_{3}\right) \delta: 7.57(\mathrm{~d}, J=9.6,1 \mathrm{H}), 6.52(\mathrm{~d}, J=12.0,1 \mathrm{H})$, $3.88(\mathrm{~s}, 3 \mathrm{H}), 3.12(\mathrm{~m}, 1 \mathrm{H}), 1.21(\mathrm{~m}, 6 \mathrm{H})$. 


\section{3-(4-fluoro-5-isopropyl-2-methoxyphenyl)prop-2- yn-1-ol (5)}

Under $\mathrm{N}_{2}$ atmosphere, to a solution of the compound 4 (35 g, $120 \mathrm{mmol})$ and propargyl alcohol(20 g, $360 \mathrm{mmol}$, $3 \mathrm{eq})$ in dry THF $(1000 \mathrm{~mL})$, and the mixture was cooled to $0^{\circ} \mathrm{C}$ with an ice-bath, was added copper(I) iodide (22.68 g, $120 \mathrm{mmol}, 1 \mathrm{eq})$ and dichlorobispalladium (70 mg, $0.1 \mathrm{mmol}$ ) stirred for $10 \mathrm{~min}$. Then triethylamine $(100 \mathrm{ml})$ was added dropwise and the reaction was stirred at room temperature for overnight. TLC and LC-MS examination showed that most of the starting material was converted into the target compound. Water was introduced to the system to quench the reaction, and the mixture was concentrated to remove most of the THF. The residual was extracted with ethyl acetate $(2 \times 50 \mathrm{~mL})$ $(\times 2)$. The combine organic solution was washed with brine and dried over anhydrous $\mathrm{MgSO}_{4}$. Purification by column chromn chromatography (200-300 mesh silica gel, $10 \% \sim 50 \%$ ethyl acetate in PE) gave final product compound 5 (22 g, yield 84\%). ESI-MS: $\left[\mathrm{M}+\mathrm{NH}_{4}\right]^{+}=$ $240,{ }^{1} \mathrm{H} \mathrm{NMR}\left(300 \mathrm{MHz}, \mathrm{CDCl}_{3}\right) \delta: 7.28(\mathrm{~d}, J=8.4,1 \mathrm{H})$, $6.54(\mathrm{~d}, J=12.0,1 \mathrm{H}), 4.54(\mathrm{~s}, 2 \mathrm{H}), 3.85(\mathrm{~s}, 3 \mathrm{H}), 3.08$ $(\mathrm{m}, 1 \mathrm{H}), 1.21(\mathrm{~m}, 6 \mathrm{H})$.

\section{3-(4-fluoro-5-isopropyl-2-methoxyphenyl) propiolaldehyde (6)}

A mixture of compound 5 (4.44 g, $20 \mathrm{mmol})$ and manganese dioxide (40 g) in dichloromethane (DCM) $(100 \mathrm{~mL})$ was stirred at ambient temperature for three days. TLC and LC-MS examination showed that most of the starting material was converted into the target compound. The reaction mixture was filtered using a membrane filter (Millipore, MillexLH, $0.45 \mu \mathrm{m}$ ), and the filtrate was concentrated to provide the compound 6 as colorless oil ( $0.65 \mathrm{~g}$, yield $94 \%)$. The crude compound 6 was used without further purification. ESI-MS: [M + $\left.\mathrm{NH}_{4}\right]^{+}=238,{ }^{1} \mathrm{H} \mathrm{NMR}\left(300 \mathrm{MHz}, \mathrm{CDCl}_{3}\right) \delta: 9.43(\mathrm{~s}, 1 \mathrm{H})$, $7.42(\mathrm{~d}, J=8.4,1 \mathrm{H}), 6.59(\mathrm{~d}, J=12.0,1 \mathrm{H}), 3.89$ (s, 3H), $3.08(\mathrm{~m}, 1 \mathrm{H}), 1.21(\mathrm{~m}, 6 \mathrm{H})$.

\section{(E)-3-(ethoxycarbonyl)-6-(4-fluoro-5-isopropyl-2- methoxyphenyl)hex-3-en-5-ynoic acid (7)}

A mixture of compound 6 (3 g, $13.6 \mathrm{mmol})$ and 4-ethoxy-4-oxo-3-(triphenyl-15-phosphanylidene) butanoic acid $(5.5 \mathrm{~g}, 13.6 \mathrm{mmol}))$ in toluene $(100 \mathrm{~mL})$ was stirred at ambient temperature overnight. TLC and LC-MS examination showed that most of the starting material was converted into the target compound. The solvent was removed by rotary evaporation. Water and ethyl acetate were added into the reaction mixture and the organic layer was washed with brine and dried over anhydrous $\mathrm{MgSO}_{4}$. After filtration and concentration, the residual was purified by column chromatography (200-300 mesh silica gel, (ethyl acetate/PE/acetic acid, 10:100:1 30:100:1v/v/v). $3.20 \mathrm{~g}$ (yield 67\%) of compound 7 was obtained as brown powder. ESI-MS: $[\mathrm{M}+\mathrm{H}]^{+}=349,{ }^{1} \mathrm{H} \mathrm{NMR}\left(300 \mathrm{MHz}, \mathrm{CDCl}_{3}\right) \delta: 7.29$ $(\mathrm{s}, 1 \mathrm{H}), 7.06(\mathrm{~s}, 1 \mathrm{H}), 6.52(\mathrm{~d}, J=12.0,1 \mathrm{H}), 4.24(\mathrm{q}, 2 \mathrm{H})$, $3.86(\mathrm{~s}, 3 \mathrm{H}), 3.77(\mathrm{~s}, 2 \mathrm{H}), 3.08(\mathrm{~m}, 1 \mathrm{H}), 1.31(\mathrm{t}, 3 \mathrm{H}), 1.21$ (m, 6H).

\section{ethyl 1-acetoxy-7-fluoro-8-isopropyldibenzo[b,d] furan-3-carboxylate (8)}

Under $\mathrm{N}_{2}$ atmosphere, to a well stirred solution of compound 7 ( $3 \mathrm{~g}, 8.6 \mathrm{mmol})$ in dry acetic anhydride $(250 \mathrm{~mL})$ was added sodium acetate $(3 \mathrm{~g}, 8.6 \mathrm{mmol})$, hydroquinone (11 $\mathrm{mg}, 0.1 \mathrm{mmol})$, and the reaction was heated at reflux for 6 hours. TLC and LC-MS examination showed that most of the starting material was converted into the target compound. The solvent was removed by rotary evaporation. The residue was diluted with $50 \mathrm{~mL}$ of ethyl acetate. The mixture was washed with water and brine and dried over anhydrous $\mathrm{Na}_{2} \mathrm{SO}_{4}$. After filtration and concentration, the residual was purified by column chromatography (200-300 mesh silica gel, 10\% 50\% ethyl acetate in PE). Totally, $2.35 \mathrm{~g}$ (yield 78\%) of target compound 8 was obtained.

ESI-MS: $\left[\mathrm{M}+\mathrm{NH}_{4}\right]^{+}=376,{ }^{1} \mathrm{H} \mathrm{NMR}(300 \mathrm{MHz}$, $\left.\mathrm{CDCl}_{3}\right) \delta: 8.13(\mathrm{~s}, 1 \mathrm{H}), 7.85(\mathrm{~s}, 1 \mathrm{H}), 7.67(\mathrm{~d}, J=7.2,1 \mathrm{H})$, $7.27(\mathrm{~d}, J=7.2,1 \mathrm{H}), 4.40(\mathrm{~m}, 2 \mathrm{H}), 3.30(\mathrm{~m}, 1 \mathrm{H}), 2.54(\mathrm{~s}$, $3 \mathrm{H}), 1.43(\mathrm{t}, 3 \mathrm{H}), 1.33(\mathrm{~m}, 6 \mathrm{H}),{ }^{13} \mathrm{C} \mathrm{NMR}\left(75 \mathrm{MHz}, \mathrm{CDCl}_{3}\right)$ $\delta: 168.44,165.62,162.71,159.42,157.18,155.67,144.30$, $131.72,129.20,121.07,120.05,119.95,117.60,110.78$, $99.48,61.50,27.45,22.80,21.01,14.34$.

\section{methyl 7-fluoro-1-hydroxy-8-isopropyldibenzo[b,d] furan-3-carboxylate (9a)}

To a well stirred solution of compound 8 $(1 \mathrm{~g}, 2.8 \mathrm{mmol})$ in $\mathrm{MeOH}(100 \mathrm{~mL})$, was added sodium methoxide (3 g, $56 \mathrm{mmol})$ in $\mathrm{MeOH}(20 \mathrm{~mL})$ in dropwise at $0^{\circ} \mathrm{C}$ with an ice-bath. The result mixture warmed to room temperature slowly and stirred until most of the compound 8 converted into the target compound 9a. After the reaction, the mixture was acidified to $\mathrm{pH}$ 1-2 with $5 \mathrm{~mL}$ acetic acid. The solvent was removed by rotary evaporation. The residue was diluted with $50 \mathrm{~mL}$ of ethyl acetate. The mixture was washed with water and brine and dried over anhydrous $\mathrm{Na}_{2} \mathrm{SO}_{4}$. The precipitated product was filtered, and purified by recrystallization from a mixed $\mathrm{MeOH} / \mathrm{H}_{2} \mathrm{O}$ solution ( $\mathrm{MeOH}: \mathrm{H}_{2} \mathrm{O} ; 3: 1$ ) to yield compound $9 \mathrm{a}(0.50 \mathrm{~g}$,yeild $59 \%)$.

ESI-MS: $\left[\mathrm{M}+\mathrm{NH}_{4}\right]^{+}=320,{ }^{1} \mathrm{H} \operatorname{NMR}(300 \mathrm{MHz}$, $\left.\mathrm{CDCl}_{3}\right) \delta: 8.01(\mathrm{~d}, J=7.5,1 \mathrm{H}), 7.82(\mathrm{~s}, 1 \mathrm{H}), 7.60(\mathrm{~s}, 1 \mathrm{H})$, $7.24(\mathrm{~d}, J=7.8,1 \mathrm{H}), 6.30$ (br, 1H), $4.00(\mathrm{~s}, 3 \mathrm{H}), 3.33(\mathrm{~m}$, $1 \mathrm{H}), 1.26(\mathrm{~m}, 6 \mathrm{H}) .{ }^{13} \mathrm{C} \mathrm{NMR}\left(75 \mathrm{MHz}, \mathrm{CDCl}_{3}\right) \delta: 167.09$, 
$158.82,157.70,155.33,150.90,131.50,128.64,120.99$, $118.67,116.89,110.13,105.98,99.34,52.53,27.42,22.96$.

\section{ethyl 7-fluoro-1-hydroxy-8-isopropyldibenzo[b,d] furan-3-carboxylate (9b)}

To a well stirred solution of compound 8 ( $0.95 \mathrm{~g}$, $3.2 \mathrm{mmol})$ in $\mathrm{MeOH}(50 \mathrm{~mL})$, was added diethylamine (DEA) $(2 \mathrm{~mL})$ in $\mathrm{MeOH}(20 \mathrm{~mL})$ in dropwise at room temperature. After the addition, the mixture was stirred at ambient temperature for 12 hours. TLC and LC-MS examination showed that most of the starting material was converted into the target compound. The solvent was removed by rotary evaporation. The mixture was acidified to $\mathrm{pH} 1-2$ with $5 \mathrm{~mL} 1 \mathrm{~N} \mathrm{HCl}$. The residue was diluted with $50 \mathrm{~mL}$ of ethyl acetate. The mixture was washed with water and brine and dried over anhydrous $\mathrm{Na}_{2} \mathrm{SO}_{4}$. The precipitated product was filtered, and purified by recrystallization from a mixed $\mathrm{MeOH} / \mathrm{H}_{2} \mathrm{O}$ solution (MeOH: $\left.\mathrm{H}_{2} \mathrm{O}=3: 1\right)$ to yield compound $9 \mathrm{~b}(0.50 \mathrm{~g}$, yeild 69\%). ESI-MS: $[\mathrm{M}-\mathrm{H}]^{-}=315,{ }^{1} \mathrm{H} \mathrm{NMR}\left(300 \mathrm{MHz}, \mathrm{CDCl}_{3}\right)$ $\delta: 8.01(\mathrm{~d}, J=7.2,1 \mathrm{H}), 7.83(\mathrm{~s}, 1 \mathrm{H}), 7.59(\mathrm{~s}, 1 \mathrm{H}), 7.23(\mathrm{~d}$, $J=7.2,1 \mathrm{H}), 6.43(\mathrm{br}, 1 \mathrm{H}), 4.42(\mathrm{q}, 2 \mathrm{H}), 3.33(\mathrm{~m}, 1 \mathrm{H}), 1.43$ (t, 3H), $1.27(\mathrm{~m}, 6 \mathrm{H}),{ }^{13} \mathrm{C} \mathrm{NMR}\left(75 \mathrm{MHz}, \mathrm{CDCl}_{3}\right) \delta$ : 165.95, 161.91, 157.51, 154.70, 153.44, 131.19, 129.61, 120.63, 119.24, 116.10, 110.19, 103.88, 100.16, 99.77, $61.43,27.43,23.18,14.63$.

\section{ethyl 1-(cyclopropylmethoxy)-7-fluoro-8- isopropyldibenzo[b,d]furan-3-carboxylate (10a)}

compound 10a was prepared from compound $9 \mathrm{~b}$ and (bromomethyl)cyclopropane as white crystal according to general method I.

ESI-MS: $[\mathrm{M}+\mathrm{H}]^{+}=371,{ }^{1} \mathrm{H} \operatorname{NMR}(300 \mathrm{MHz}$, $\left.\mathrm{CDCl}_{3}\right) \delta: 8.06(\mathrm{~d}, J=7.8,1 \mathrm{H}), 7.85(\mathrm{~s}, 1 \mathrm{H}), 7.46(\mathrm{~s}$, $1 \mathrm{H}), 7.22(\mathrm{~d}, J=7.8,2 \mathrm{H}), 4.34(\mathrm{q}, 2 \mathrm{H}), 4.14(\mathrm{~d}, J=6.9$, $2 \mathrm{H}), 3.32(\mathrm{~m}, 1 \mathrm{H}), 1.46(\mathrm{t}, 3 \mathrm{H}), 1.40(\mathrm{~m}, 1 \mathrm{H}), 1.33(\mathrm{~d}, J$ $=6.9,6 \mathrm{H}), 0.71(\mathrm{~m}, 2 \mathrm{H}), 0.52(\mathrm{~m}, 2 \mathrm{H}),{ }^{13} \mathrm{C} \operatorname{NMR}(75$ $\mathrm{MHz}, \mathrm{CDCl}_{3}$ ) $\delta: 166.54,161.97,158.71,157.16,157.13$, 155.22, 155.03, 154.19, 131.46, 131.24, 129.34, 120.95, $120.86,119.09,119.07,117.69,106.15,99.22,98.83$, $72.84,61.28,27.39,22.89,14.38,10.25,3.00$.

\section{ethyl 7-fluoro-1-(hexyloxy)-8-isopropyldibenzo[b,d] furan-3-carboxylate (10b)}

compound $10 \mathrm{~b}$ was prepared from compound $9 \mathrm{~b}$ and 1-bromohexane as white crystal according to general method I. ESI-MS: $[\mathrm{M}+\mathrm{H}]^{+}=401,{ }^{1} \mathrm{H}$ NMR $(300 \mathrm{MHz}$, $\left.\mathrm{CDCl}_{3}\right) \delta: 8.01(\mathrm{~d}, J=7.5,1 \mathrm{H}), 7.85(\mathrm{~s}, 1 \mathrm{H}), 7.49(\mathrm{~s}, 1 \mathrm{H})$, $7.22(\mathrm{~d}, J=6.2,1 \mathrm{H}), 4.42(\mathrm{q}, 2 \mathrm{H}), 4.26(\mathrm{t}, 2 \mathrm{H}), 3.32(\mathrm{~m}$, $1 \mathrm{H}), 1.97(\mathrm{~m}, 2 \mathrm{H}), 1.63(\mathrm{~m}, 2 \mathrm{H}), 1.42(\mathrm{~m}, 4 \mathrm{H}), 1.26(\mathrm{~d}$, $J=6.9,6 \mathrm{H}), 0.92(\mathrm{t}, 3 \mathrm{H}),{ }^{13} \mathrm{C} \mathrm{NMR}\left(75 \mathrm{MHz}, \mathrm{CDCl}_{3}\right) \delta$ :
166.56, 161.92, 158.66, 157.16, 157.33, 155.20, 155.01, 154.32, 131.43, 131.21, 129.37, 120.82, 120.73, 119.09, $119.07,117.52,106.05,105.86,99.21,98.83,68.51,61.27$, $31.64,29.27,27.31,27.24,22.91,22.70,14.38,14.04$.

\section{ethyl 1-(cyclohexylmethoxy)-7-fluoro-8- isopropyldibenzo[b,d]furan-3-carboxylate (10c)}

compound 10c was prepared from compound $9 \mathrm{~b}$ and (bromo methyl)cyclohexane as white crystal according to general method I.

ESI-MS: $[\mathrm{M}+\mathrm{H}]^{+}=413,{ }^{1} \mathrm{H} \operatorname{NMR}(300 \mathrm{MHz}$, $\left.\mathrm{CDCl}_{3}\right) \delta: 8.04(\mathrm{~d}, J=7.5,1 \mathrm{H}), 7.85(\mathrm{~s}, 1 \mathrm{H}), 7.47(\mathrm{~s}$, $1 \mathrm{H}), 7.22$ (d, $J=7.8,2 \mathrm{H}), 4.40$ (q, 2H), 4.08 (d, $J=5.4$, $2 \mathrm{H}), 3.32(\mathrm{~m}, 1 \mathrm{H}), 2.00(\mathrm{~m}, 3 \mathrm{H}), 1.88(\mathrm{~m}, 2 \mathrm{H}), 1.76(\mathrm{~m}$, $1 \mathrm{H}), 1.47(\mathrm{t}, 3 \mathrm{H}), 1.29(\mathrm{~d}, J=6.9,6 \mathrm{H}), 1.15(\mathrm{~m}, 6 \mathrm{H}),{ }^{13} \mathrm{C}$ $\operatorname{NMR}\left(75 \mathrm{MHz}, \mathrm{CDCl}_{3}\right) \delta: 166.58,161.89,158.63,157.14$, 157.11, 155.19, 155.01, 154.45, 131.41, 131.19, 129.38, $120.75,120.66,119.11,119.08,117.59,106.01,105.83$, $99.20,98.82,73.79,61.27,38.06,30.01,27.10,27.06$, $26.54,25.91,22.91,14.39$.

\section{ethyl7-fluoro-8-isopropyl-1-((4-methoxybenzyl) oxy)dibenzo[b,d]furan-3-carboxylate (10d)}

compound 10d was prepared from compound $9 \mathrm{~b}$ and 1-(bromo methyl)-4-methoxybenzene as white crystal according to general method I.

ESI-MS: $[\mathrm{M}+\mathrm{NH} 4]^{+}=454,{ }^{1} \mathrm{H}$ NMR $(300 \mathrm{MHz}$, $\left.\mathrm{CDCl}_{3}\right) \delta: 7.99(\mathrm{~d}, J=7.5,1 \mathrm{H}), 7.89(\mathrm{~s}, 1 \mathrm{H}), 7.61(\mathrm{~s}$, $1 \mathrm{H}), 7.51(\mathrm{~d}, J=8.4,2 \mathrm{H}), 7.22(\mathrm{~d}, J=7.5,1 \mathrm{H}), 6.98(\mathrm{~d}$, $J=8.4,2 \mathrm{H}), 5.31$ (s, 2H), 4.40 (q, 2H), 3.87 (s, 3H), 3.28 $(\mathrm{m}, 1 \mathrm{H}), 1.43(\mathrm{t}, 3 \mathrm{H}), 1.29(\mathrm{~d}, J=6.9,6 \mathrm{H}),{ }^{13} \mathrm{C} \operatorname{NMR}(75$ $\mathrm{MHz}, \mathrm{CDCl}_{3}$ ) $\delta: 166.48,159.58,158.75,157.20,155.27$, $153.88,131.53,131.31,129.37,128.94,128.67,120.94$, $120.85,118.96,118.92,117.84,114.03,106.49,99.26$, $98.88,70.40,61.32,55.35,27.37,27.33,22.83,14.39$.

\section{cyclopropylmethyl7-fluoro-1-(hexyloxy)-8- isopropyldibenzo[b,d]furan-3-carboxylate (11a)}

compound 11a was prepared from compound $10 \mathrm{~b}$ and (bromomethyl)cyclopropane as white crystal according to general method II and general method III.

ESI-MS: $[\mathrm{M}+\mathrm{H}]^{+}=427,{ }^{1} \mathrm{H} \operatorname{NMR}(300 \mathrm{MHz}$, $\left.\mathrm{CDCl}_{3}\right) \delta: 8.01(\mathrm{~d}, J=7.5,1 \mathrm{H}), 7.89(\mathrm{~s}, 1 \mathrm{H}), 7.51(\mathrm{~s}, 1 \mathrm{H})$, $7.22(\mathrm{~d}, J=7.5,1 \mathrm{H}), 4.42(\mathrm{t}, 2 \mathrm{H}), 4.20(\mathrm{~d}, J=7.2,2 \mathrm{H})$, $3.33(\mathrm{~m}, 1 \mathrm{H}), 1.95(\mathrm{~m}, 2 \mathrm{H}), 1.63(\mathrm{~m}, 2 \mathrm{H}), 1.42(\mathrm{~m}, 4 \mathrm{H})$, $1.26(\mathrm{~d}, J=6.9,6 \mathrm{H}), 0.92(\mathrm{t}, 3 \mathrm{H}), 0.62(\mathrm{~m}, 2 \mathrm{H}), 0.42$ $(\mathrm{m}, 2 \mathrm{H}),{ }^{13} \mathrm{C} \mathrm{NMR}\left(75 \mathrm{MHz}, \mathrm{CDCl}_{3}\right) \delta: 166.70,161.92$, 158.66, 157.16, 157.13, 155.02, 154.35, 131.43, 131.21, $129.40,120.83,120.74,119.08,117.53,106.12,105.92$, $99.23,98.84,70.23,68.52,31.65,29.27,27.31,27.27$, $25.99,22.92,22.71,14.06,9.96,3.37$. 
cyclopropylmethyl7-fluoro-8-isopropyl-1((4-methoxybenzyl)oxy)dibenzo[b,d]furan-3carboxylate (11b)

compound $11 \mathrm{~b}$ was prepared from compound $10 \mathrm{~d}$ and (bromomethyl)cyclopropane as white crystal according to general method II and general method III.

ESI-MS: $\left[\mathrm{M}+\mathrm{NH}_{4}\right]^{+}=480,{ }^{1} \mathrm{H} \mathrm{NMR}(300 \mathrm{MHz}$, $\left.\mathrm{CDCl}_{3}\right) \delta: 7.99(\mathrm{~d}, J=7.5,1 \mathrm{H}), 7.92(\mathrm{~s}, 1 \mathrm{H}), 7.62(\mathrm{~s}, 1 \mathrm{H})$, $7.51(\mathrm{~d}, J=8.4,2 \mathrm{H}), 7.23(\mathrm{~d}, J=10.2,1 \mathrm{H}), 6.97(\mathrm{~d}, J=$ $8.7,2 \mathrm{H}), 5.33(\mathrm{~s}, 2 \mathrm{H}), 4.20(\mathrm{~d}, J=7.2,3 \mathrm{H}), 3.87(\mathrm{~s}, 3 \mathrm{H})$, $3.28(\mathrm{~m}, 1 \mathrm{H}), 1.29(\mathrm{~d}, J=6.9,6 \mathrm{H}), 1.26(\mathrm{~m}, 1 \mathrm{H}), 0.63(\mathrm{~m}$, $2 \mathrm{H}), 0.39(\mathrm{~m}, 2 \mathrm{H}),{ }^{13} \mathrm{C} \mathrm{NMR}\left(75 \mathrm{MHz}, \mathrm{CDCl}_{3}\right) \delta: 166.59$, $159.57,157.21,157.18,155.28,155.09,153.88,131.52$, $131.30,129.40,128.95,128.67,120.95,120.85,118.94$, $117.84,114.04,106.56,99.27,98.88,70.40,70.06,55.35$, $27.38,27.34,22.83,9.96,3.38,3.38$.

\section{cyclohexylmethyl7-fluoro-1-(hexyloxy)-8- isopropyldibenzo[b,d]furan-3-carboxylate (11c)}

compound $11 \mathrm{c}$ was prepared from compound $10 \mathrm{~b}$ and (bromomethyl)cyclohexane as white crystal according to general method II and general method III.

ESI-MS: $[\mathrm{M}+\mathrm{H}]^{+}=469,{ }_{1}^{1} \mathrm{H}$ NMR $(300 \mathrm{MHz}$, $\left.\mathrm{CDCl}_{3}\right) \delta: 8.01(\mathrm{~d}, J=7.5,1 \mathrm{H}), 7.85(\mathrm{~s}, 1 \mathrm{H}), 7.49(\mathrm{~s}, 1 \mathrm{H})$, 7.22 (d, $J=7.2,2 \mathrm{H}), 4.28$ (t, 2H), 4.17 (d, $J=6.3,2 \mathrm{H})$, $3.32(\mathrm{~m}, 1 \mathrm{H}), 1.99(\mathrm{~m}, 2 \mathrm{H}), 1.82(\mathrm{~m}, 6 \mathrm{H}), 1.62(\mathrm{~m}, 2 \mathrm{H})$, $1.41(\mathrm{~m}, 4 \mathrm{H}), 1.26(\mathrm{~m}, 4 \mathrm{H}), 1.23(\mathrm{~d}, J=6.9,6 \mathrm{H}), 1.13(\mathrm{~m}$, $6 \mathrm{H}), 0.88(\mathrm{t}, 3 \mathrm{H}),{ }^{13} \mathrm{C} \mathrm{NMR}\left(75 \mathrm{MHz}, \mathrm{CDCl}_{3}\right) \delta: 166.61$, $161.92,158.66,157.15,157.12,155.19,155.01,154.36$, $131.44,131.22,129.42,120.83,120.75,119.10,119.07$, $117.51,105.97,105.91,99.20,98.82,70.36,68.51,37.32$, $31.65,29.81,29.26,27.32,27.28,26.39,25.98,25.73$, 22.91, 22.70, 14.05 .

\section{cyclohexylmethyl7-fluoro-8-isopropyl-1-((4- methoxybenzyl)oxy)dibenzo[b,d]furan-3- carboxylate (11d)}

compound 11d was prepared from compound 10d and (bromomethyl)cyclohexane as white crystal according to general method II and general method III.

ESI-MS: $[\mathrm{M}+\mathrm{H}]^{+}=505,\left[\mathrm{M}+\mathrm{NH}_{4}\right]^{+}=522,{ }^{1} \mathrm{H}$ $\operatorname{NMR}\left(300 \mathrm{MHz}, \mathrm{CDCl}_{3}\right) \delta: 7.99(\mathrm{~d}, J=7.5,1 \mathrm{H}), 7.88(\mathrm{~s}$, $1 \mathrm{H}), 7.60(\mathrm{~s}, 1 \mathrm{H}), 7.51(\mathrm{~d}, J=8.4,2 \mathrm{H}), 7.23(\mathrm{~d}, J=10.2$, $1 \mathrm{H}), 6.91(\mathrm{~d}, J=8.7,2 \mathrm{H}), 5.33(\mathrm{~s}, 2 \mathrm{H}), 4.18(\mathrm{~d}, J=6.0$, $3 \mathrm{H}), 3.86(\mathrm{~s}, 3 \mathrm{H}), 3.29(\mathrm{~m}, 1 \mathrm{H}), 1.72(\mathrm{~m}, 6 \mathrm{H}), 1.29(\mathrm{~d}$, $J=6.9,6 \mathrm{H}), 1.26(\mathrm{~m}, 4 \mathrm{H}), 0.88(\mathrm{~m}, 2 \mathrm{H}),{ }^{13} \mathrm{C}$ NMR $(75$ $\mathrm{MHz}, \mathrm{CDCl}_{3}$ ) $\delta: 166.51,162.02,159.57,157.20,157.16$, 155.26, 155.08, 153.88, 131.54, 131.32, 129.41, 128.91, $128.65,120.95,120.85,118.96,118.94,117.83,114.04$, $113.78,106.58,106.42,99.25,98.87,70.39,55.34,37.31$, $29.81,27.39,27.36,26.39,25.74,22.83$. 1-(cyclopropylmethoxy)-7-fluoro-8isopropyldibenzo[b,d]furan-3-carboxylic acid (11e)

compound 11e was prepared from compound 10a as white crystal according to general method II. ESIMS: $[\mathrm{M}-\mathrm{H}]^{-}=341,{ }^{1} \mathrm{H}$ NMR(300 MHz, $d_{6}$-DMSO ) $\delta$ : $13.21(\mathrm{br}, 1 \mathrm{H}), 7.99(\mathrm{~d}, J=7.5,1 \mathrm{H}), 7.77(\mathrm{~s}, 1 \mathrm{H}), 7.63(\mathrm{~d}$, $J=7.8,1 \mathrm{H}), 7.44(\mathrm{~s}, 1 \mathrm{H}), 4.16(\mathrm{~d}, J=6.6,2 \mathrm{H}), 3.22(\mathrm{~m}$, $1 \mathrm{H}), 1.21(\mathrm{~m}, 2 \mathrm{H}), 1.29(\mathrm{~d}, J=6.9,6 \mathrm{H}), 0.57(\mathrm{~m}, 2 \mathrm{H}), 0.48$ $(\mathrm{m}, 2 \mathrm{H}),{ }^{13} \mathrm{C}$ NMR( $75 \mathrm{MHz}, d_{6}$-DMSO) $\delta: 167.44,161.73$, $158.49,156.97,154.97,154.77,154.28,131.48,131.26$, $131.03,120.61,120.52,119.09,117.50,116.72,106.94$, $105.95,100.28,99.89,72.72,27.30,23.12,10.48,3.19$.

\section{PTP activity assay}

Human recombinant PTP-MEG2, SHP2 and CDC25 were expressed in E. coli and purified by NiNTA affinity chromatography in our laboratory. The basic chemical reaction catalyzed by a phosphatase converts a phosphosubstrate into a dephosphorylated product and free phosphate which could be measured as a surrogate for phosphatase activity. pNPP(para-nitrophenyl phosphate) was used as phosphatase substrate which can be hydrolyzed by phosphatase to give para-nitrophenol. Subsequently, para-nitrophenol converts into paranitrophenolate (pNP) with addition of sodium hydroxide stop solution. pNP is an intense yellow compound and could be measured at $405 \mathrm{~nm}$ using a spectrophotometer. To begin with, purified recombinant PTP-MEG2, SHP2 and CDC25 $(0.05 \mu \mathrm{g})$ in $50 \mu \mathrm{L}$ buffer with $50 \mathrm{mM}$ citrate (pH 6.0), $0.1 \mathrm{M} \mathrm{NaCl}, 1 \mathrm{mM}$ EDTA, and $1 \mathrm{mM}$ dithiothreitol (DTT) and test compounds were added to each well of a 96-well plate. Blank was prepared by omitting enzyme and substituting an equivalent volume of buffer. After preincubation for $15 \mathrm{~min}$ at room temperature, $50 \mu \mathrm{L}$ of reaction buffer with $2 \mathrm{mM}$ pNPP was added and incubated at $37^{\circ} \mathrm{C}$ for $30 \mathrm{~min}$. Then, the reaction was stopped by adding $10 \mu \mathrm{L} 0.2 \mathrm{M}$ sodium hydroxide and chilled on ice quickly. In addition, the amount of pNP was measured by detecting the absorption at $405 \mathrm{~nm}$ against blank. Finally, $\mathrm{IC}_{50}$ values were determined by analyzing the data using ORIGINPRO 8 software.

3D-common feature hypotheses generation and validation using the HipHop Method

A data set of 8 compounds (Figure 2) for which in vitro inhibitory activities against the PTP-MEG2 enzyme synthesized in our lab were used as training set to develop a common feature 3D-pharmacophore model. Before the generation of pharmacophore hypotheses, the training set compounds were converted into $3 \mathrm{D}$ structure to generate diverse conformations using the Diverse Conformation Generation protocol implemented in Discovery studio v3.5. Per molecule will generate the maximum numbers of 200 conformations to ensure 
maximum coverage of the conformational space by using Best conformation model generation method with CHARMm force field [32] and Poling algorithm [33-36] module implemented in Discovery studio v3.5 was used to construct pharmacophore model in order to offer promising scaffolds for the development of novel and potent PTP-MEG2 inhibitors. The common feature pharmacophore generation used in this study was obtained by defining two properties-Pincipal and MaxOmitFeat of the ligands in the dataset that determined which molecules should be considered when building the pharmacophore space and which molecules should map to all or some of the features in the final pharmacophore. The Principal value of 2 and MaxOmitFeat value of 0 were assigned to the most active compounds (10a and 11d), which meant their structure and conformation would have the strongest influence in the model building phase. For the rest of the compounds, the Principal value of 1 and MaxOmitFeat value of 1 were assigned, which meant this molecule could partially map onto the hypothesis generated by the search procedure and all but one of the features in the generated pharmacophore must map to the compound. Selecting the chemical feature is one of the most important steps in generating pharmacophore. Due to the basic structures of the compounds and their proposed mechanism of action by Feature Mapping module from DS, four kinds of features including hydrogen-bond acceptor (HBA), hydrogenbond donor (HBD), hydrophobic group (Hyd), and ring aromatic (RA) features were selected to initiate the pharmacophore hypotheses generation process. Moreover, the number of features of any particular type was allowed to vary from 0 to 5 for $\mathrm{HBA}, 0$ to 5 for $\mathrm{HBD}, 1$ to 5 for Hyd, and 1 to 5 for RA. All other parameters remained at their default settings.

Figure 2 PTP-MEG2 inhibitors used in common feature pharmacophore generation.

After automatic hypothesis generation, ten common features hypotheses with ranking scores were selected by the HipHop program. The ranking is a measure of how well the molecules map onto the proposed pharmacophores and the rarity of the pharmacophore model. However, the ranked first pharmacophore may not be the best pharmacophore model, and thus it is necessary to analyze all of them to determine which hypothesis was an accurate representation of the observed data. The derived pharmacophore map was validated based on Receiver operating characteristic (ROC) analysis to assess their abilities to selectively capture diverse PTP-MEG2 inhibitors from a large list of decoys. The decoys normally are selected from the zinc database, which are presumed to be similar to active ligands and be inactive against a target. The decoy set was generated using DecoyFinder [37]. A data set of 3 compounds for which

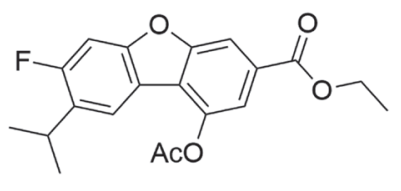

8

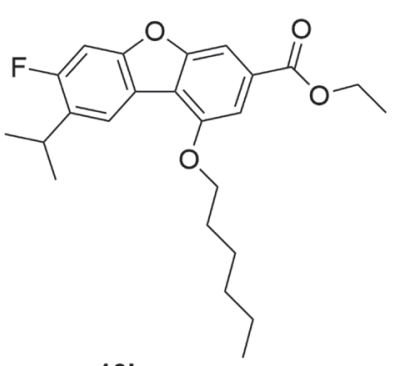

10b

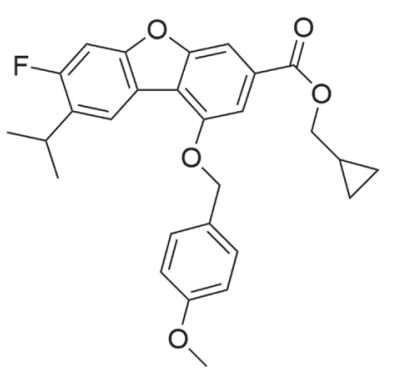

11b

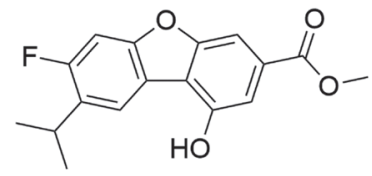

$9 a$
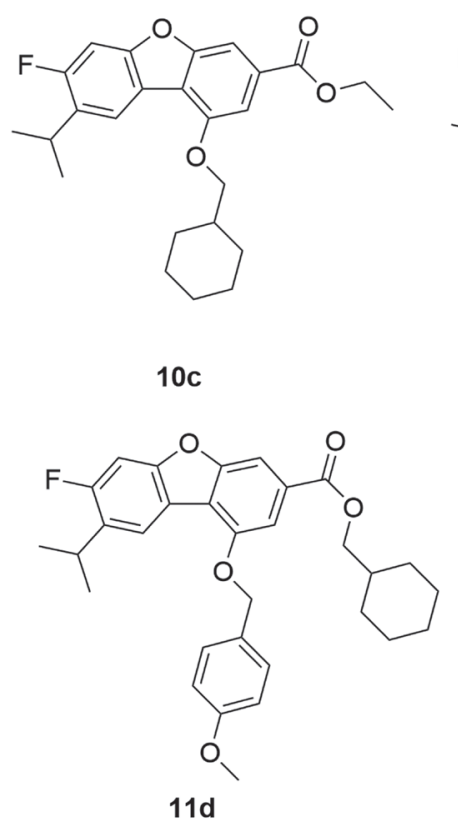

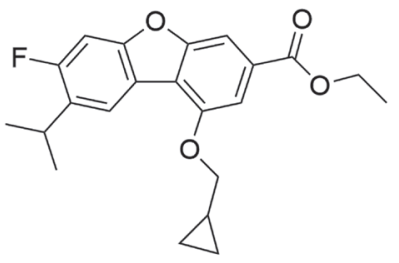

$10 a$

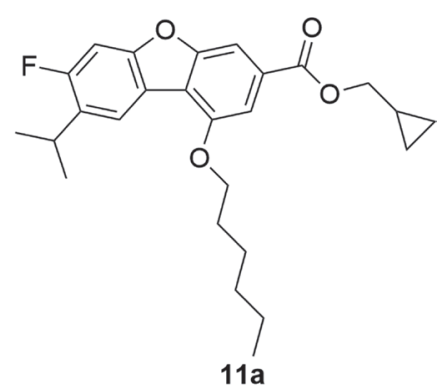

$11 a$

Figure 2: PTP-MEG2 inhibitors used in common feature pharmacophore generation. 
in vitro inhibitory activities against the PTP-MEG2 enzyme synthesized in our lab were used as active molecules to search the decoy set by using the MACCS fingerprints and five physical descriptors [38-40]. The physical descriptors of a decoy are considered to be similar to those of an active ligand if the following conditions are met: (i) the molecular weight is within $25 \mathrm{Da}$ of the active ligand; (ii) they contain the same number \pm 1 of rotational bonds and HBDs, and the same number \pm 2 of HBAs; and (iii) the Log $P$ value is within 1.0 of the active ligand. The Tanimoto coefficients [27] between the MACCS fingerprints of each potential decoy and active molecule are then calculated. The Tanimoto coefficients between a potential decoy and each of the active molecules are not greater than 0.75 . Thus, decoys are chemically different from any of the active molecules of the query. Finally, the decoys were generated such that each ligand has 30 decoys. The ROC testing set was screened by each pharmacophore for ROC analysis employing the "Best rigid search" option implemented in CATALYST, while the Maximum Omitted Features was set to -1 . The default values for other parameters were kept constant. The ROC analysis validates pharmacophore model by analysis of sensitivity ( $\mathrm{Se}$ ) and specialty ( $\mathrm{Sp}$ ). In an optimal ROC curve, the value of the area under ROC curve (AUC) is 1 ; while random distributions cause the AUC value of 0.5 . The AUC value needs to be between 0.5 and 1 . The higher the value is, the better the discrimination is.

\section{Molecular docking}

The Flexible Docking tool [41] embedded in Discovery Studio v3.5 was used as an efficient tool to monitor the interactions between ligands and target proteins. During the docking process, the selected side chains of amino acids and conformations of ligands are flexible. The preparation and refinement protocols for the protein receptor and all compound structures were performed on the Prepare Protein Wizard and Prepare Ligands modules embedded in the Discovery Studio v3.5. PTP-MEG2 (PDB ID: 4GE6) [20] was prepared by removing water, adding the hydrogen atoms, deleting alternate conformations, standardizing atom names and the ligands were prepared by the procedures of removing duplicates, enumerating isomers, tautomers, and ionization states [42] at a given $\mathrm{pH}$ range and generating 3D conformations. Define and Edit binding site tool embedded in Discovery Studio v3.5 was applied to calculate a binding site from a selected ligand. The P-loop (residues 514-521), the pTyr recognition loop (residues 331-338), and the Q-loop (residues 558-564) of PTP-MEG2 were selected to be used for creating protein conformations and side-chain refinement in the presence of the ligand [43]. All the investigated compounds were docked into the receptor pocket via the flexible protein docking model with the CDOCKER [44] scoring function to estimate the binding affinities.

\section{ADME prediction}

ADME properties are a crucial aspect of clinical candidate quality. Approximately 39\% of drugs were failing in development because of poor biopharmaceutical properties. With the high cost of development, this failure represented a major economic loss for the companies as well as the discovery of a new drug product was delayed. Lipinski's rule of five [45] is a rule of thumb to evaluate druglikeness or determine if a chemical compound would become a likely orally active drug in humans. The components of the rule are as follows: 1) No more than 5 hydrogen bond donors. 2) No more than 10 hydrogen bond acceptors. The increasing number of hydrogen bonds may reduce partitioning from the aqueous phase into the lipid bilayer membrane for permeation by passive diffusion. 3) A molecular mass less than 500 daltons. Increasing molecular weight (MW) reduces the compound concentration at the surface of the intestinal epithelium, which reduces absorption.4) An octanol-water partition coefficient log P not greater than 5. Increasing $\log P$ also decreases aqueous solubility, thus reducing absorption. The polar surface area (PSA) is another determinant of fraction absorption. Structure properties determine physicochemical and biochemical properties, which ultimately determine pharmacokinetics and toxicity.

Calculations of important ADME properties of dibenzofuran derivatives were performed through Discovery Studio v3.5, USA (2013). With this software, a total of 15 categories of descriptors or molecular properties can be predicted, including the principal descriptors and pharmacokinetic properties. Molecular descriptors include 2D parameters (e.g., AlogP [46], molecular weight, number of aromatic ring, number of $\mathrm{H}$-acceptors, number of $\mathrm{H}$-donors, number of rings, number of aromatic rings, number of rotatable bonds, and molecular fraction polar surface area $[47,48])$. The property analyses for van der Waals surface area of polar nitrogen and oxygen atoms (PSA), predicted aqueous solubility (Solubility) [49], human intestinal absorption[50, 51], blood brain barrier (ADMET_BBB_Level)[52], cytochrome p450 2D6 (ADMET_EXT_CYP2D6\#Pre -diction) [53, 54], plasma protein binding (ADMET_EXT_PPB) [54-56] and hepatotoxicity (ADMET_EXT_Hepatotoxic\#Prediction) $[57,58]$, were considered in the Discovery Studio v3.5 to evaluate the acceptability of the compounds.

\section{Authors' contributions}

Conceived and designed the experiments: YM,HYW. Performed the experiments: YM YZZ HLL. Analyzed the data: YM WYJ RLW HLL HZ. Contributed reagents/materials/analysis tools: RLW,XCC. Wrote the paper: YM. 


\section{CONFLICTS OF INTEREST}

The authors declare that they have no conflicts of interest.

\section{FUNDING}

This work was supported by the Natural Natural Science Foundations of China (Grant No. 81273361), the Natural Science Foundation of Tianjin (Grant No. 16JCZDJC32500) and the International (Regional) Cooperation and Exchange Project of the National Natural Science Foundation of China (Grant No. 81611130090).

\section{REFERENCES}

1. Tonks NK. Protein tyrosine phosphatases: from genes, to function, to disease. Nat Rev Mol Cell Biol. 2006; 7:833-846.

2. Zhang ZY. Protein tyrosine phosphatases: prospects for therapeutics. Curr Opin Chem Biol. 2001; 5:416-423.

3. Julien SG, Dube N, Hardy S, Tremblay ML. Inside the human cancer tyrosine phosphatome. Nat Rev Cancer. 2011; 11:35-49.

4. Pomorski A, Adamczyk J, Bishop AC, Krezel A. Probing the target-specific inhibition of sensitized protein tyrosine phosphatases with biarsenical probes. Org Biomol Chem. $2015 ; 13: 1395-1403$.

5. Yi T, Lindner D. The role and target potential of protein tyrosine phosphatases in cancer. Curr Oncol Rep. 2008; $10: 114-121$

6. Kruger JM, Fukushima T, Cherepanov V, Borregaard N, Loeve C, Shek C, Sharma K, Tanswell AK, Chow CW, Downey GP. Protein-tyrosine phosphatase MEG2 is expressed by human neutrophils. Localization to the phagosome and activation by polyphosphoinositides. J Biol Chem. 2002; 277:2620-2628.

7. Gu M, Warshawsky I, Majerus PW. Cloning and expression of a cytosolic megakaryocyte protein-tyrosine-phosphatase with sequence homology to retinaldehyde-binding protein and yeast SEC14p. Proc Natl Acad Sci USA. 1992; 89:2980-2984.

8. Qi Y, Zhao R, Cao H, Sui X, Krantz SB, Zhao ZJ. Purification and characterization of protein tyrosine phosphatase PTP-MEG2. J Cell Biochem. 2002; 86:79-89.

9. Huynh H, Wang X, Li W, Bottini N, Williams S, Nika K, Ishihara H, Godzik A, Mustelin T. Homotypic secretory vesicle fusion induced by the protein tyrosine phosphatase MEG2 depends on polyphosphoinositides in $\mathrm{T}$ cells. J Immunol. 2003; 171:6661-6671.

10. Zhang D, Marlin MC, Liang Z, Ahmad M, Ashpole NM, Sonntag WE, Zhao ZJ, Li G. The Protein Tyrosine Phosphatase MEG2 Regulates the Transport and Signal Transduction of Tropomyosin Receptor Kinase A. J Biol Chem. 2016; 291:23895-23905.
11. Wang X, Huynh H, Gjorloff-Wingren A, Monosov E, Stridsberg M, Fukuda M, Mustelin T. Enlargement of secretory vesicles by protein tyrosine phosphatase PTPMEG2 in rat basophilic leukemia mast cells and Jurkat T cells. J Immunol. 2002; 168:4612-4619.

12. Zhao R, Fu X, Li Q, Krantz SB, Zhao ZJ. Specific interaction of protein tyrosine phosphatase-MEG2 with phosphatidylserine. J Biol Chem. 2003; 278:22609-22614.

13. Hao Q, Samten B, Ji HL, Zhao ZJ, Tang H. Tyrosine phosphatase PTP-MEG2 negatively regulates vascular endothelial growth factor receptor signaling and function in endothelial cells. Am J Physiol Cell Physiol. 2012; 303:C548-553.

14. Su F, Ren F, Rong Y, Wang Y, Geng Y, Wang Y, Feng M, Ju Y, Li Y, Zhao ZJ, Meng K, Chang Z. Protein tyrosine phosphatase Meg2 dephosphorylates signal transducer and activator of transcription 3 and suppresses tumor growth in breast cancer. Breast Cancer Res. 2012; 14:R38.

15. Saito K, Williams S, Bulankina A, Honing S, Mustelin T. Association of protein-tyrosine phosphatase MEG2 via its Sec14p homology domain with vesicle-trafficking proteins. J Biol Chem. 2007; 282:15170-15178.

16. Xu MJ, Sui X, Zhao R, Dai C, Krantz SB, Zhao ZJ. PTP-MEG2 is activated in polycythemia vera erythroid progenitor cells and is required for growth and expansion of erythroid cells. Blood. 2003; 102:4354-4360.

17. Cho CY, Koo SH, Wang Y, Callaway S, Hedrick S, Mak PA, Orth AP, Peters EC, Saez E, Montminy M, Schultz PG, Chanda SK. Identification of the tyrosine phosphatase PTPMEG2 as an antagonist of hepatic insulin signaling. Cell Metab. 2006; 3:367-378.

18. Wang Y, Vachon E, Zhang J, Cherepanov V, Kruger J, Li J, Saito K, Shannon P, Bottini N, Huynh H, Ni H, Yang H, McKerlie C, et al. Tyrosine phosphatase MEG2 modulates murine development and platelet and lymphocyte activation through secretory vesicle function. J Exp Med. 2005; 202:1587-1597.

19. Yuan T, Wang Y, Zhao ZJ, Gu H. Protein-tyrosine phosphatase PTPN9 negatively regulates ErbB2 and epidermal growth factor receptor signaling in breast cancer cells. J Biol Chem. 2010; 285:14861-14870.

20. Zhang S, Liu S, Tao R, Wei D, Chen L, Shen W, Yu ZH, Wang L, Jones DR, Dong XC, Zhang ZY. A highly selective and potent PTP-MEG2 inhibitor with therapeutic potential for type 2 diabetes. J Am Chem Soc. 2012; 134:18116-18124.

21. Wang MY, Li XB, Dong L, Chen XB, Xu WR, Wang RL. Virtual screening, optimization, and identification of a novel specific PTP-MEG2 Inhibitor with potential therapy for T2DM. Oncotarget. 2016; 7:50828-50834. doi: 10.18632/ oncotarget.10341.

22. Takaya Y, Kikuchi H, Terui Y, Komiya J, Maeda Y, Ito A, Oshima Y. Novel aromatic substances, dictyomedin A, B, from Dictyostelium cellular slime molds and their inhibitory effects on Dictyostelium development. Tetrahedron Lett. $2001 ; 42: 61-63$. 
23. Nimis PL, Skert N. Lichen chemistry and selective grazing by the coleopteran Lasioderma serricorne. Environ Exp Bot. 2006; 55:175-182.

24. Sonogashira K, Tohda Y, Hagihara N. Convenient synthesis of acetylenes: catalytic substitutions of acetylenic hydrogen with bromoalkenes, iodoarenes, and bromopyridines. Tetrahedron Lett. 1975; 16:4467-4470.

25. Serra S, Fuganti C. A new preparative route to substituted dibenzofurans by benzannulation reaction. An application to the synthesis of cannabifuran. Synlett. 2003; 2005-2008.

26. Irwin JJ, Shoichet BK. ZINC-a free database of commercially available compounds for virtual screening. J Chem Inf Model. 2005; 45:177-182.

27. Kirchmair J, Markt P, Distinto S, Wolber G, Langer T. Evaluation of the performance of 3D virtual screening protocols: RMSD comparisons, enrichment assessments, and decoy selection - what can we learn from earlier mistakes? J Comput Aided Mol Des. 2008; 22:213-228.

28. Triballeau N, Acher F, Brabet I, Pin JP, Bertrand HO. Virtual screening workflow development guided by the "receiver operating characteristic" curve approach. Application to high-throughput docking on metabotropic glutamate receptor subtype 4. J Med Chem. 2005; 48:2534-2547.

29. Bissantz C, Kuhn B, Stahl M. A medicinal chemist's guide to molecular interactions. J Med Chem. 2010; 53:5061-5084.

30. Ozawa T, Tsuji E, Ozawa M, Handa C, Mukaiyama H, Nishimura T, Kobayashi S, Okazaki K. The importance of CH/ pi hydrogen bonds in rational drug design: An ab initio fragment molecular orbital study to leukocyte-specific protein tyrosine (LCK) kinase. Bioorg Med Chem. 2008; 16:10311-10318.

31. Wolber G, Langer T. LigandScout: 3-D pharmacophores derived from protein-bound ligands and their use as virtual screening filters. J Chem Inf Model. 2005; 45:160-169.

32. MacKerell AD, Banavali N, Foloppe N. Development and current status of the CHARMM force field for nucleic acids. Biopolymers. 2001; 56:257-265.

33. Micheli F, Pasquarello A, Tedesco G, Hamprecht D, Bonanomi G, Checchia A, Jaxa-Chamiec A, Damiani F, Davalli S, Donati D, Gallotti C, Petrone M, Rinaldi M, et al. Diaryl substituted pyrrolidinones and pyrrolones as 5-HT2C inhibitors: synthesis and biological evaluation. Bioorg Med Chem Lett. 2006; 16:3906-3912.

34. Smellie A, Kahn SD, Teig SL. Analysis of Conformational Coverage. 1. Validation and Estimation of Coverage. J Chem Inf Comput Sci. 1995; 35:285-294.

35. Smellie A, Kahn SD, Teig SL. Analysis of Conformational Coverage. 2. Applications of Conformational Models. J Chem Inf Comput Sci. 1995; 35:295-304.

36. Smellie A, Teig S, Towbin P. Poling: Promoting Conformational Variation. J Comput Chem. 1995; 16:171-187.

37. Cereto-Massague A, Guasch L, Valls C, Mulero M, Pujadas G, Garcia-Vallve S. DecoyFinder: an easy-to-use python GUI application for building target-specific decoy sets. Bioinformatics. 2012; 28:1661-1662.
38. Wallach I, Lilien R. Virtual decoy sets for molecular docking benchmarks. J Chem Inf Model. 2011; 51:196-202.

39. Durant JL, Leland BA, Henry DR, Nourse JG. Reoptimization of MDL keys for use in drug discovery. J Chem Inf Comput Sci. 2002; 42:1273-1280.

40. O'Boyle NM, Banck M, James CA, Morley C, Vandermeersch T, Hutchison GR. Open Babel: An open chemical toolbox. J Cheminform. 2011; 3:33.

41. Koska J, Spassov VZ, Maynard AJ, Yan L, Austin N, Flook PK, Venkatachalam CM. Fully automated molecular mechanics based induced fit protein-ligand docking method. J Chem Inf Model. 2008; 48:1965-1973.

42. Spassov VZ, Yan L. A fast and accurate computational approach to protein ionization. Protein Sci. 2008; 17:1955-1970.

43. Spassov VZ, Yan L, Flook PK. The dominant role of side-chain backbone interactions in structural realization of amino acid code. ChiRotor: A side-chain prediction algorithm based on sidechain backbone interactions. Protein Sci. 2007; 16:494-506.

44. Wu G, Robertson DH, Brooks CL 3rd, Vieth M. Detailed analysis of grid-based molecular docking: A case study of CDOCKER-A CHARMm-based MD docking algorithm. J Comput Chem. 2003; 24:1549-1562.

45. Lipinski CA, Lombardo F, Dominy BW, Feeney PJ. Experimental and computational approaches to estimate solubility and permeability in drug discovery and development settings. Adv Drug Deliv Rev. 2001; 46:3-26.

46. Ghose AK, Crippen GM. Atomic physicochemical parameters for three-dimensional-structure-directed quantitative structureactivity relationships. 2. Modeling dispersive and hydrophobic interactions. J Chem Inf Comput Sci. 1987; 27:21-35.

47. Ertl P, Rohde B, Selzer P. Fast calculation of molecular polar surface area as a sum of fragment-based contributions and its application to the prediction of drug transport properties. J Med Chem. 2000; 43:3714-3717.

48. Shrake A, Rupley JA. Environment and exposure to solvent of protein atoms. Lysozyme and insulin. J Mol Biol. 1973; 79:351-371.

49. Cheng A, Merz KM Jr. Prediction of aqueous solubility of a diverse set of compounds using quantitative structureproperty relationships. J Med Chem. 2003; 46:3572-3580.

50. Egan WJ, Merz KM Jr, Baldwin JJ. Prediction of drug absorption using multivariate statistics. J Med Chem. 2000; 43:3867-3877.

51. Egan WJ, Lauri G. Prediction of intestinal permeability. Adv Drug Deliv Rev. 2002; 54:273-289.

52. Egan WJ, Walters WP, Murcko MA. Guiding molecules towards drug-likeness. Curr Opin Drug Discov Devel. 2002; 5:540-549.

53. Susnow RG, Dixon SL. Use of robust classification techniques for the prediction of human cytochrome P450 2D6 inhibition. J Chem Inf Comput Sci. 2003; 43:1308-1315.

54. Wesson L, Eisenberg D. Atomic solvation parameters applied to molecular dynamics of proteins in solution. Protein Sci. 1992; 1:227-235. 
55. Dixon SL, Merz KM Jr. One-dimensional molecular representations and similarity calculations: methodology and validation. J Med Chem. 2001; 44:3795-3809.

56. Votano JR, Parham M, Hall LM, Hall LH, Kier LB, Oloff $\mathrm{S}$, Tropsha A. QSAR modeling of human serum protein binding with several modeling techniques utilizing structure-information representation. J Med Chem. 2006; 49:7169-7181.
57. Cheng A, Dixon SL. In silico models for the prediction of dose-dependent human hepatotoxicity. J Comput Aided Mol Des. 2003; 17:811-823.

58. Xia X, Maliski EG, Gallant P, Rogers D. Classification of kinase inhibitors using a Bayesian model. J Med Chem. 2004; 47:4463-4470. 